\title{
METALLIZATION AND POST-MINERAL HYPOGENE ARGILLIZATION, LOST RIVER TIN MINE, ALASKA
}

\section{L. SAINSBURY}

CONTENTS

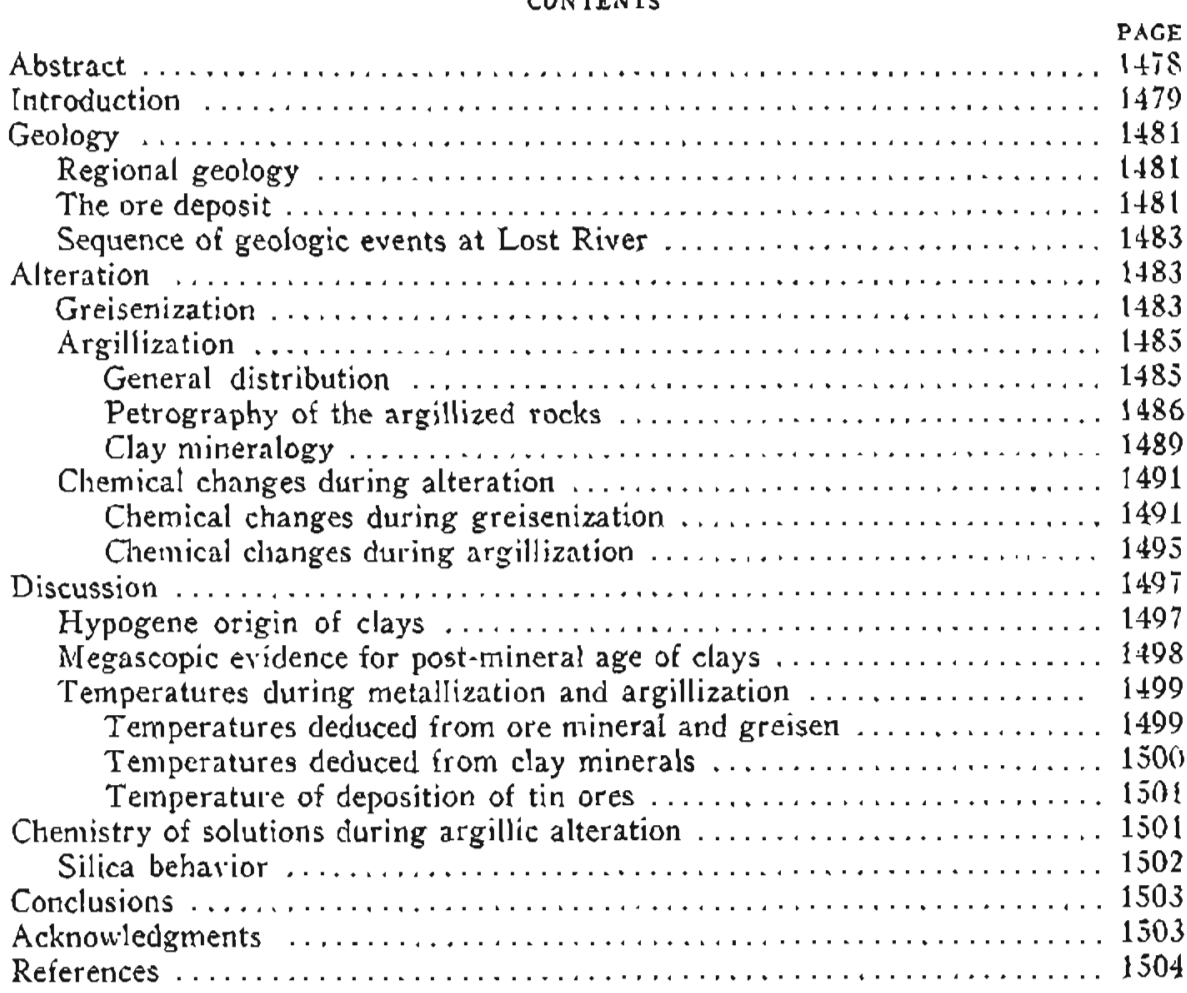

\section{ABSTRACT}

The Lost River tin and tungsten deposit occurs in a buried granite piuton and in associated rhyolite dikes that intrude Paleozoic limestone. The dikes and parts of the granite were greisenized and then argillized irregularly. Hetallization accompanied greisenization rather than argillization, althoing both processes probably were closely related in time.

Iron-zinc ratios in sphalerite indicate that the ore minerals were deposited at a temperature between $425^{\circ} \mathrm{C}$ and $740^{\circ} \mathrm{C}$. This temperature is within the range of the temperatures at which topaz. a comman associate of the ore nimerals, has been synthesized in the laboratory. The temperature of deposition of the ore minerals is above the temperature interval in which clay minerals are stable. Thus. clay minerals could not have formed 1 Fullicarion atuthorized by the Director, Ii. S. Geological Surrey. 


$$
\begin{aligned}
& \text { to Gim williums widk regars } \\
& \text { Dete Aainakny }
\end{aligned}
$$


while ore was being deposited. As temperatures fell and entered the stability range of the clay minerals, argillic alteration encroached upon greisen ores and wall rocks.

Reaction rims between quartz and topaz indicate that krolinite could have formed according to the following reaction:

$$
\begin{gathered}
\text { topaz }+ \text { quartz }+ \text { water + limestone } \rightarrow \text { kaolinite }+ \text { fluorite }+\begin{array}{c}
\text { carbonic } \\
\text { acid }
\end{array} \\
(\mathrm{Al}, \mathrm{P})_{2} \mathrm{SiO}_{4}+\mathrm{SiO}_{2}+3 \mathrm{H}_{3} \mathrm{O}+\mathrm{CaCO}_{3} \rightarrow \mathrm{M}_{2} \mathrm{Si}_{4} \mathrm{O}_{8}(\mathrm{OH})_{4}+\mathrm{CaF}_{2}+\mathrm{H}_{2} \mathrm{CO}_{3}
\end{gathered}
$$

The clay minerals, which formed fron diverse rock types, consist of kaolinite, dickite, mixed-lavered chlorite-nontmorillonite, and minor montmorillonite, accompanied by variable amounts of muscovite and zinnwaldite. The dickite is most common in and near late veins that cut the earlier-formed greisen.

Temperature is believed to be the principal agent governing the relations between ore deposition and argillization. Similar relations are to be expected in other high-temperature deposits where abundant veining and fracturing indicate that wall rocks reached an isothermal condition above a masimum temperature of $480^{\circ} \mathrm{C}$ during ore deposition.

\section{INTRODUCTION}

THE argillized rock at Lost River mine was studied through detailed mapping underground and by the separation and identification in the laboratory of sufficient samples of clay to establish the general mineralogy of the clays. The results warrant discussion because of the clear-cut independence of argillization and metallization, and because of their bearing on questions raised in some of the many recent papers on hydrothermal alteration (especially 49. 37, 30, 7, 2). The relations at Lost River apparently are similar to those described from Cornwall-type cassiterite deposits in many parts of the world, and the same sequence of metallization followed by hypogene argillization probably is repeated at many places (especially 61 ).

The main purposes of this paper are to record the time and space relations at Lost River and to emphasize the importance of temperature as a controlling factor in high-temperature alteration. In many cases cited in the literature, the temperature of deposition of the ores is inferred from the minerals in the associated argillized rocks. In too few cases has the temperature of deposition of the ore minerals been first determined, and the argillic products then discussed in relation to that temperature. The writer feels that inferences regarding the temperature of ore deposition that are based upon the associated argillic alteration minerals may often rest on tenuous grourids, and may be analgous to offering the theorem as proof of itself.

By use of pressure bombs, many workers have investigated in the laboratory the formation and stability ranges of the minerals commonly found in argillic alteration $(41,24,25,26,18,48,47,8,40)$, and the results of these investigations are exerting a strong influence on interpretation of the processes of hydrothermal alteration. Recent laboratory studies that more closely cluplicate hydrothermal systems than pressure-bomb experiments have been made by otlier workers $(42,21,39,25,27)$. Field studies of natural springs

I Kaolinite formula as suggested by Dr. H. S, Yoder of the Geophysical Laboritory of the Carnegie Institute. 
have been of great value in correlating laboratory results with field interpretation $(14,19,59,64)$.

General studies correlating alteration and metallization have been made throughout the world. and a substantial literature on the subject has accumulated. The conmon workl-wirle accurrence of types and suites of alteration products is applarent. Comversely, some major differences are evident, especiatly in the interpretation of the line relations between metallization and alteralion, as is well shown by tlie papers of Sales and Meyers (49, Lovering et al. (37) and Tuoker (60). Sales and Meyer conclude that argillization at Butte, Montana, developed simultaneously with ore deposition from oreforming fuids that did not change noticeally in composition at the source. Lovering postulates that in the East Tintic district, Utah, different argillic phases predating ore were formed by "surges" of hydrothermal fluids of notably different composition. Tooker concludes that the argillization at Central City, Colorado, was premineral.

Lindgren (35) pointed out as early as 1915 that kaolinite could not form above $470^{\circ} \mathrm{C}$. Roy and Osborne (47) established $405^{\circ} \mathrm{C}$ as the upper stability limit for kaolinite, nacrite and dickite. The present writer believes that more thought should be given to the upper limiting stability range of the clay minerals in discussions of argillic alteration associated with mesothermal and hypothermal ore deposits. Such deposits include the cassiteritetype tin deposits, the pyrometasomatic deposits, and possibly the disseminated deposits found in the igneous rocks with which they are genetically associated, as, for instance, the porphyry copper deposits.

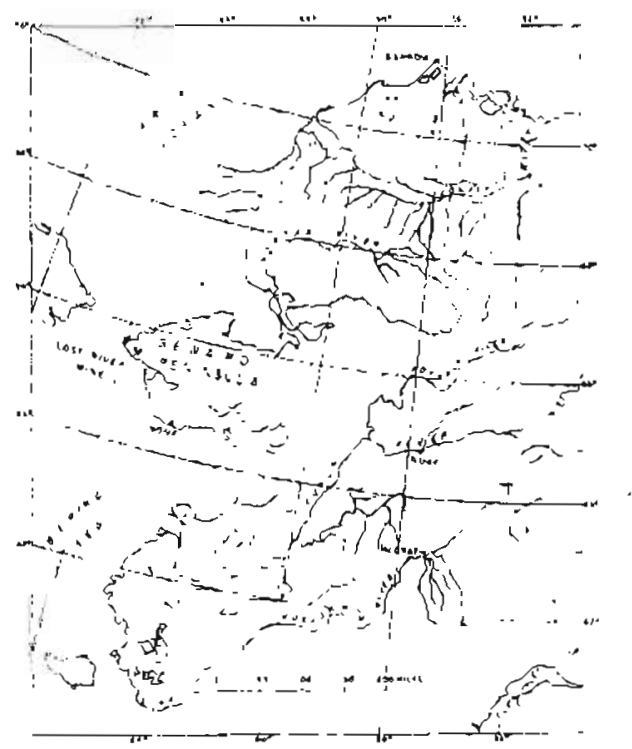

[ik. 1. Inclex mal) of western Alaska, showing location of Lost River mine. 


\section{GEOLOGY}

\section{Regional Geology}

Lost River mine is near the western tip of the Seward Peninsula, Alaska, approximately 90 miles northwesterly from Nome (Fig. 1), in the York Mountains. The bedrock of most of this part of the Seward Peninsula consists of Paleozoic limestones intruded by granite stocks and both felsic and mafic dikes. The Lost River deposit is at the southern margin of a distinct metallogenetic province where cassiterite is associated with granite plutons widely spaced over an area of several hundred square miles (31, $57,58)$.

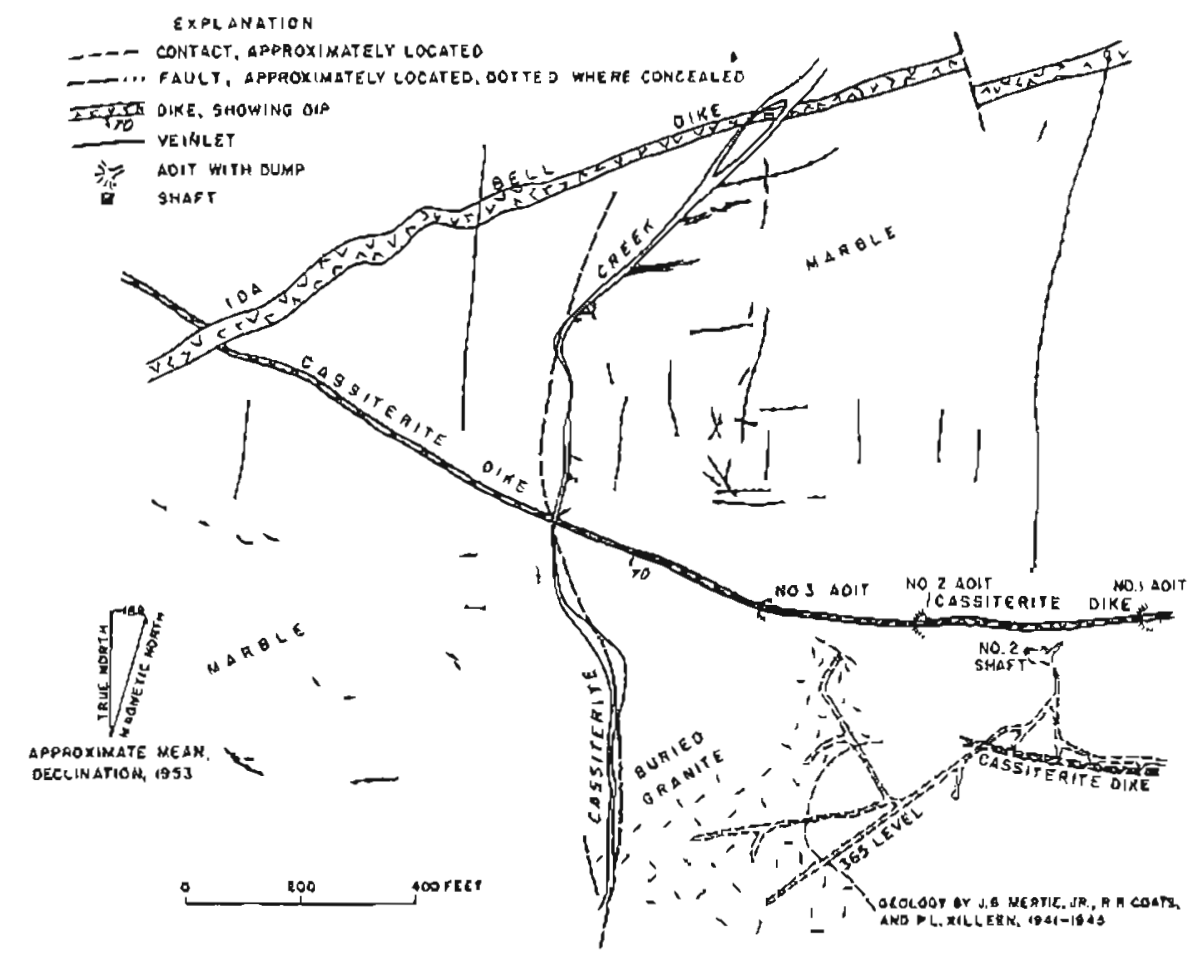

Fag. 2. Geologic map of Lost River mine.

THE ORE DEPOSIT

The deposit at Lost River is a cassiterite-wollramite deposit associated with a granite pluton that intrucies the limestone, and with basaltic and rhyolitic dikes spatially associated with the granite. The granite does not crop out, but is penetrated by exploratory mine openings driven from the main workings, which lie along an altered rhyolite porphyry dike. The deposit that has been explored consists of two ore zones: a main ore shoot localized along a rhyolite porphyry dike, named the Cassiterite dike, near its intersection 
with a second rhyolite porphyry dike named the Ida Bell dike; and a surrounding zone of low-grade ore in the granite pluton and in the veined and metsomatized marble overlying the granite. No dikes have been found in the granite, and the granite has intruded at least one of the basaltic dikes. The relations indicate that the dikes are pregranite. The geology at the mine is shown in Figure 2.

The configuration of the main tin ore shoot is shown in Figure 3, which is a longitudinal projection along the Cassiterite dike. The tungsten-rich ore lies beneath the tin ore shoot. All the ore mined to date has come from the Cassiterite dike. The main ore mineral is cassiterite, which is in tactite that

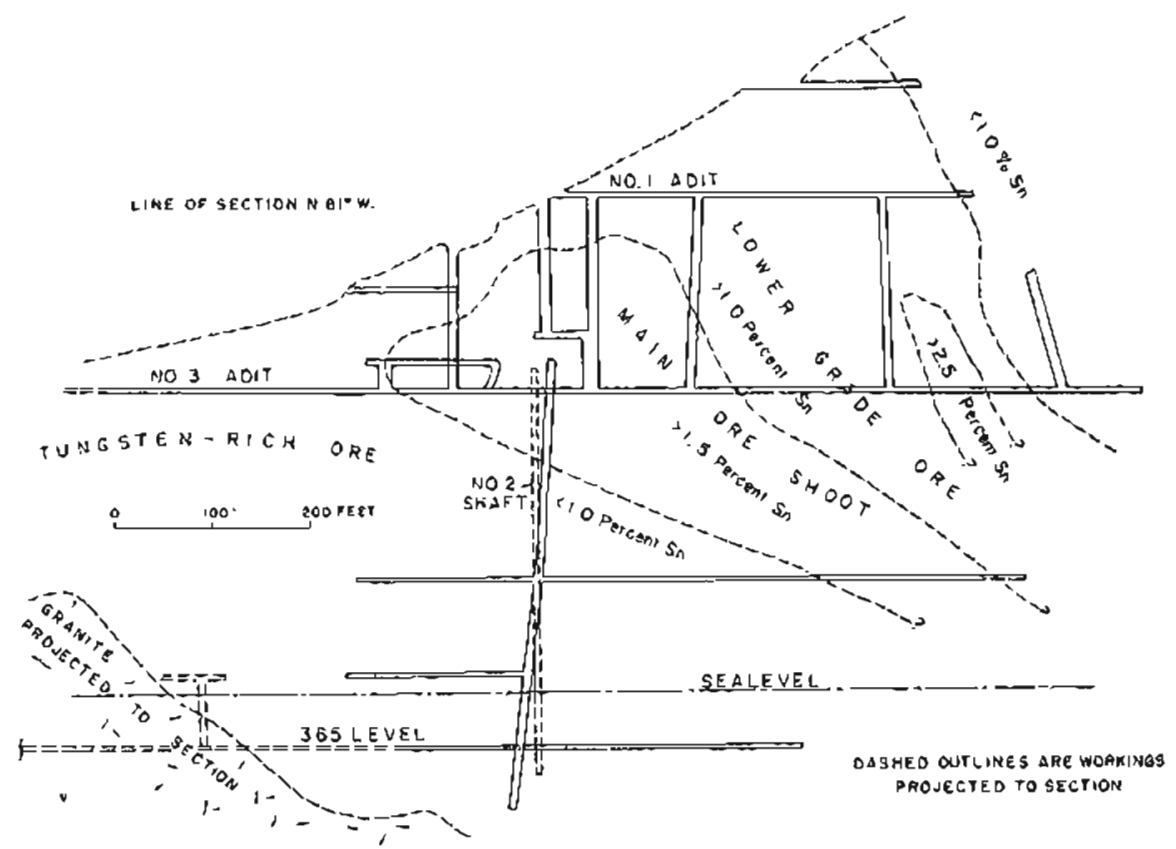

FIG. 3. Longitudinad projection, Lost River tin mine, showing main ore shoot.

is localized along planes of weakness such as dike walls, in small veinlets that cut granite, dike, and marble, and disseminated in greisenized dike rock and granite. Other identified minerals are wolframite, arsenopyrite, pyrite, galena, ferroan sphalerite, chalcopyrite. molybdenite, stannite, bismuthinite, stibnite, scheelite, pyrrhotite, hematite, ilmenite, magnetite, rutile, phenacite, beryl, and chalcocite. These minerals are herein referred to collectively as ore minerals. The main gangue minerals are quartz, topaz, fluorite, tourmaline, zinnwaldite, muscovite, garnet, caicite, siderite, hornblende, pyroxene, plagioclase, gypsum, and the various clay minerals discussed under "alteration."

Thus the Lost River deposit is seen to be a typical high-temperature tin- 
tungsten cleposit of the Cornwall type, but with limestone wall rocks, and an associated argillic phase.

\section{Sequence of Geologic Events at Lost River}

The sequence of geologic events at Lost River is believed to be as follows :

(1) Regional faulting of the Paleozoic limestone.

(2) Injection of dikes along normal faults.

(3) Intrusion of the granite pliton.

(4) Renewed faulting along older faults that shattered some of the dikes, and possibly parts of the granite,

(5) Intense pneumatolytic activity at temperatures above $425^{\circ} \mathrm{C}$ (the minimum temperature at which the ferroan sphalerite could have been deposited), with accompanying greisenization and metallization of shattered dikes, and parts of the granite. Veins formed along fractures in the limestone.

(6) Continued fracturing during the pneumatolytic stage with some movement localized along the Cassiterite dike to form veinlets oriented parallel or subparallel to the dike. Greiscn previously formed was cut by younger greisen veinfets.

(7) Probable sealing of most fractures.

(8) Falling temperature.

(9) Renewed deformation to open channels that did not coincide exactly with those that were open during metallization.

(10) Hydrothermal activity at low to moderate pressures, and at temperatures below an absolute maximum of $480^{\circ} \mathrm{C}$ (the maximum temperature at which a clay mineral has been reported stable (48)), with accompanying argillic alteration of much of the greisen, marble, and tactite without recognizable deposition of ore minerals, but with some modification of pre-existing sulfide minerals, particularly iron sulfides.

(11) Renewed fanlting along the normal fault occupied by the Cassiterite slike, and probal)ly along other faults.

(12) Cooling.

(13) Minor faulting along the fault occupied by the Cassiterite dike.

\section{ALTERATION}

Alteration at Lost River comprises two distinct types: greisenization of sranite and rhyolite, with concomitant formation of tactite from marble, and complex argillic alteration.

\section{Greisenization}

Greisenization was most intense along the Cassiterite dike and within a restricted part of the granite pluton. The dike was greisenized so completely that no fresh clike rock has been found in any of the existing mine openings. The dike rock that appears treshest in hand specimen resembles a hard gray to white quartz porphyry with disseminated sulfide minerals 

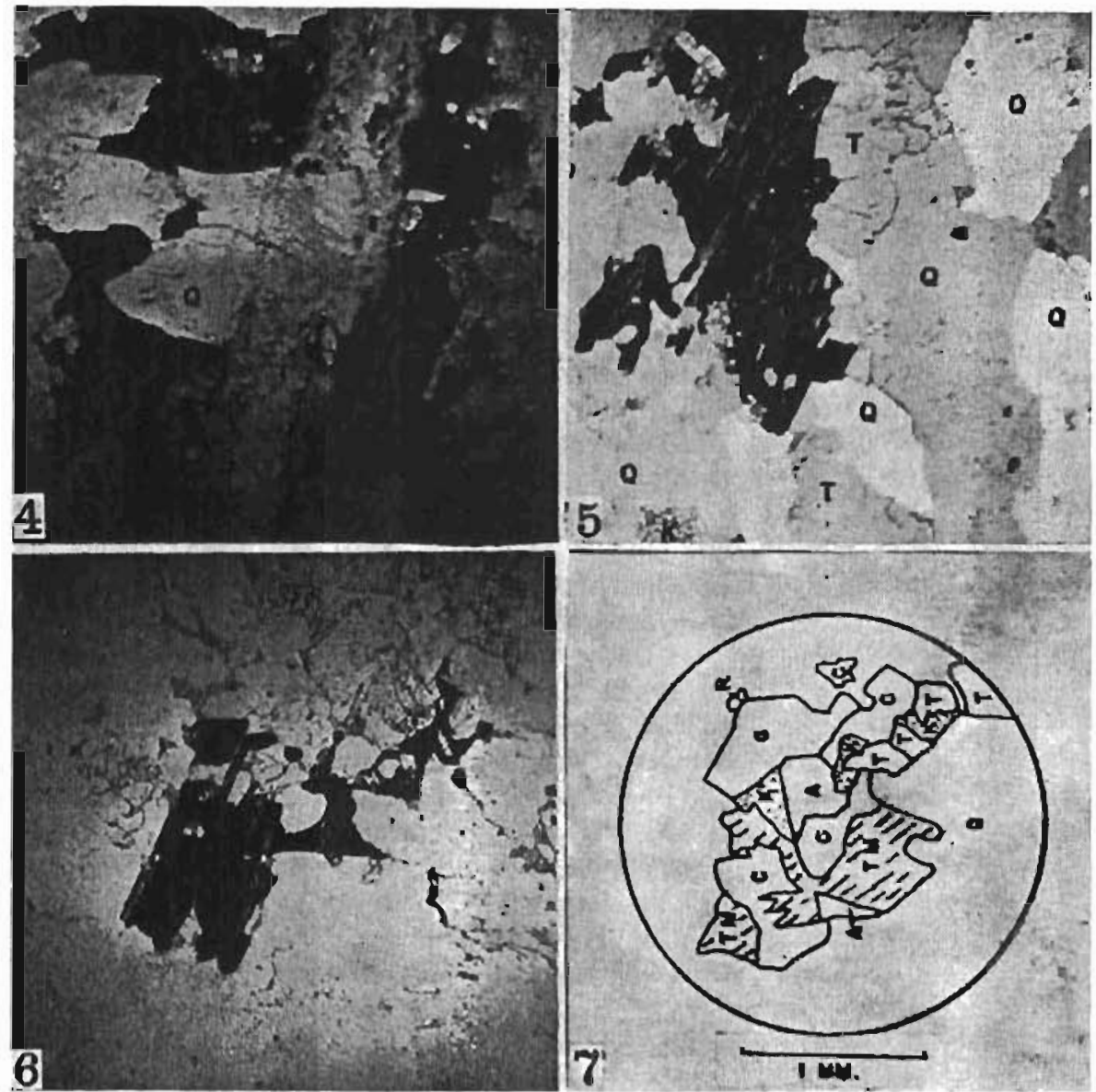

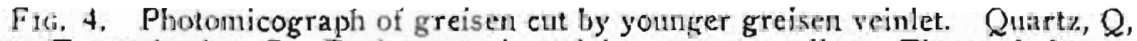
topnaz $T$, cassiterite, $C$. Dark areas in veinlat are toummaline. The rock is not irgillized. Uncrossed nicols.

Fic. 5. Photomicrographs of greisen with sullide mineral retaining relict texture inlierited from mica. Partly crossed nicols. Note lack of argillization. Pyrite, $P$, copaz, $T$, quirtz, $Q$.

FIG. 6. Photomicrograph of greisen showing complex sulfide replacenent of mica. Pyrite is partly replaced by younger sulfide materials. Note rery faint argillization. Uncrossed nicols.

FIG. 7. Drawing from a photomicrograph of greisen showing intimate relation of sulíide minerals in a single thin section. Chalcopyrite, $C$, galena, $G$, irsenopyrite, $\mathrm{A}$, rutile, $\mathrm{R}$, tourmaline, $\mathrm{T}, \mathrm{I}$, topaz, $\mathrm{T}$, and kaolinite, $\mathrm{K}$. In other sections, ferroan sphalerite, pyrite and molvbdenite are found in unargillized greisen.

and cassiterite. Sucl rock consists chiefly of yuart\% and topaz and herein is called greisen although it contains less mica than the typical greisen. Some specimens contain a little mica, however. The morlal composition of the greisen varies from sanple to sample, but quartz generally predomimites 
over topaz. In samples of greisen low in sulfide minerais, white mica forms a few percent of the rock, but as the content of sulficle minerals increases, the unica decreases because of its susceptibility to replacement by the sulfide nuinerals. Topaz reaches a naximum of ahout $40-45$ percent. and is a pure fluorine variety, which contains 21.6 percent of fuorine as determined by chemical analysis. ${ }^{1}$ The greisen is cut by later veinlets of greisen, some of which are very rich in cassiterite (Fig. 4). Masses of such greisen are exposed in mine workings on the Cassiterite dike and in the underlying granite. The greisen in the dike was mined as ore, but even the richer parts of the underlying greisenized granite are of signficantly lower grade when minable tonnages are considered. Much of the greisen is unargillized, but fragments of greisen are found as relicts in completely argillized rhyolite or granite.

Sulfide-bearing greisen similar to that found at Lost River is described at many of the world's tin deposits $(54,29,28,27,63,62)$, and presumably it is a common rock type.

The sulfide minerals in the greisen display a crucle paragenetic securence beginning with early pyrite which entered the greisen initially as a replacement of mica. This early pyrite retains a "shredded" texture inherited from the mica it replaced (Figs. 5 and 6 ). Other strlfide minerals replace early pyrite (Fig. 7), and such second-cycle replacement often results in the destruction of the "shred" texture. In specimens containing a large amount of ore minerals (as much as several percent), all nica is replaced. Single specimens of unargillized greisen have been found that contain alnost all the ore minerals, such as pyrite. arsenopyrite, ferroan sphalerite, galena, chalcopyrite, rutile, magnetite, and molyblenite. All greisen contains several of the ore minerais. This important relation suggests that the greisen is pre-argillic and was metallized prior to argillic alteration, or that both greisen and argillized rock were pre-mineral, and the greisen was more scitable, physically and chemically, for replacement than argillized rock. Abundant megascopic and microscopic eviclence supports the first conclusion. No direct evidence has been found that supports the second conclusion, and in fact the occurrence of disseminated grains of various ore minerals in some highly argillized rock refutes it.

\section{Argillizadion}

Gencral Distribution,-The argillized rocks at Lost River display a complex clistribution that resembles on a small scale the regional relations described for parts of the Cornwall deposits by Ussher, Barrow and McAlister (61). The Cassiterite dike was extensively argillized far beyond the limits of the commercial ore. At places, the linestone or tactite wall rocks along the dike were extensively argillized. In general, both the degree of argillization and the volume of argillized limestone increase neas the granite, but the relation is not a simple one. The granite pluton also was extensively argillized, but in irregular fashion. Figure 8 shows the broad distribution

1 Analy'sts: Paul W. Scote, Samuel D. Botts, U. S. Geological Survey. 
of Eresh granite, greisenized granite, and argillized rock on the lowest level of the mine where the pluton is intersected by mine workings.

Figures 9 and 10 depict relations exposed by mining in the upper levels of the mine on the Cassiterite dike. The important feature depicted by Figures 9 and 10 is the independence of argillic alteration and ore-bearing veinlets. Certainly the evidence is clear cut that the argillized rock is not an alteration envelope around an ore-bearing vein. Individual veinlets such as shown in Figures 9 and 10 can be traced from fresh greisen through argillized greisen at many places in the mine.

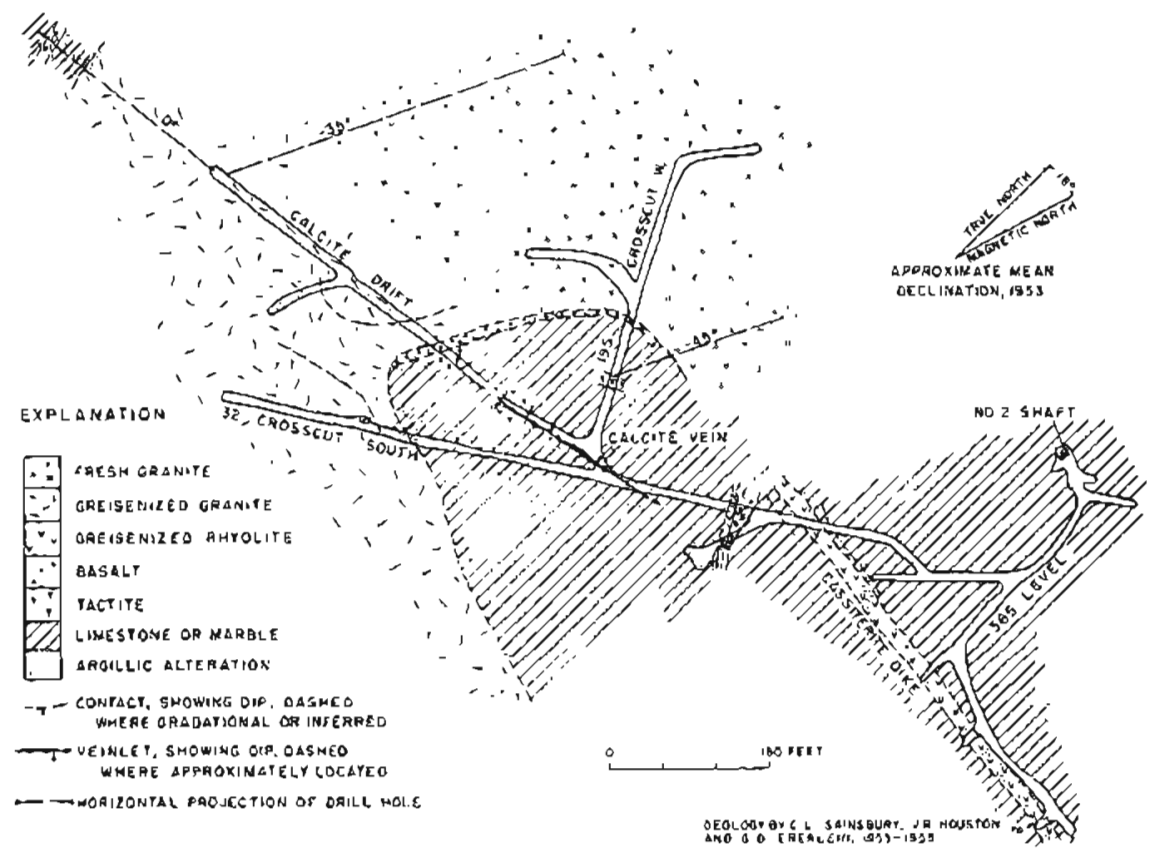

FiG. 8. Generalized geologic map, 365 level, Lost River mine, showing distribution of alteration.

Petrography of the Argillized Rocks.-Brief descriptions are given here to show the development of argillization of three of the main rock types shown in Figures 8-10, as observed under the microscope.

The freshest granite found at Lost River is slightly altered. The granite cut by the 195 crosscut west consists of a bone-white, faintly porphyritic granite with hypautomorphic-granular texture. Its modal composition in percent is quartz, 45 ; oligoclase, 20 ; orthoclase, 30 ; the remainder consists of white mica, a non-pleochroic chloritic mica of very low refringence, and minor fluorite, which generally is associated with mica. Some of the white mica is faintly pleochroic in shades of brown, suggesting that it was altered from biotite. Some thin sections of granite show a grain or two of tourmaline 


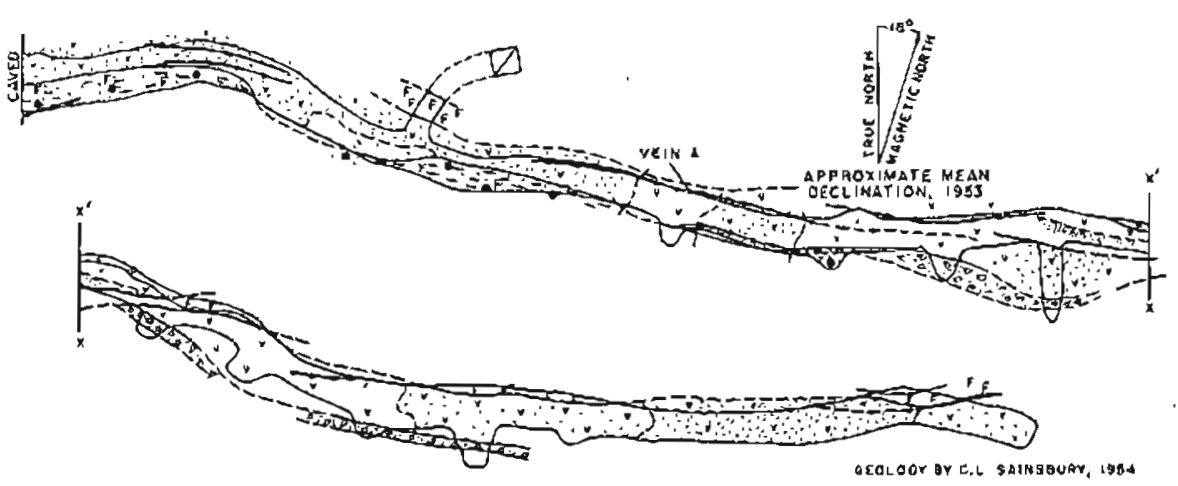

EXPLANATION
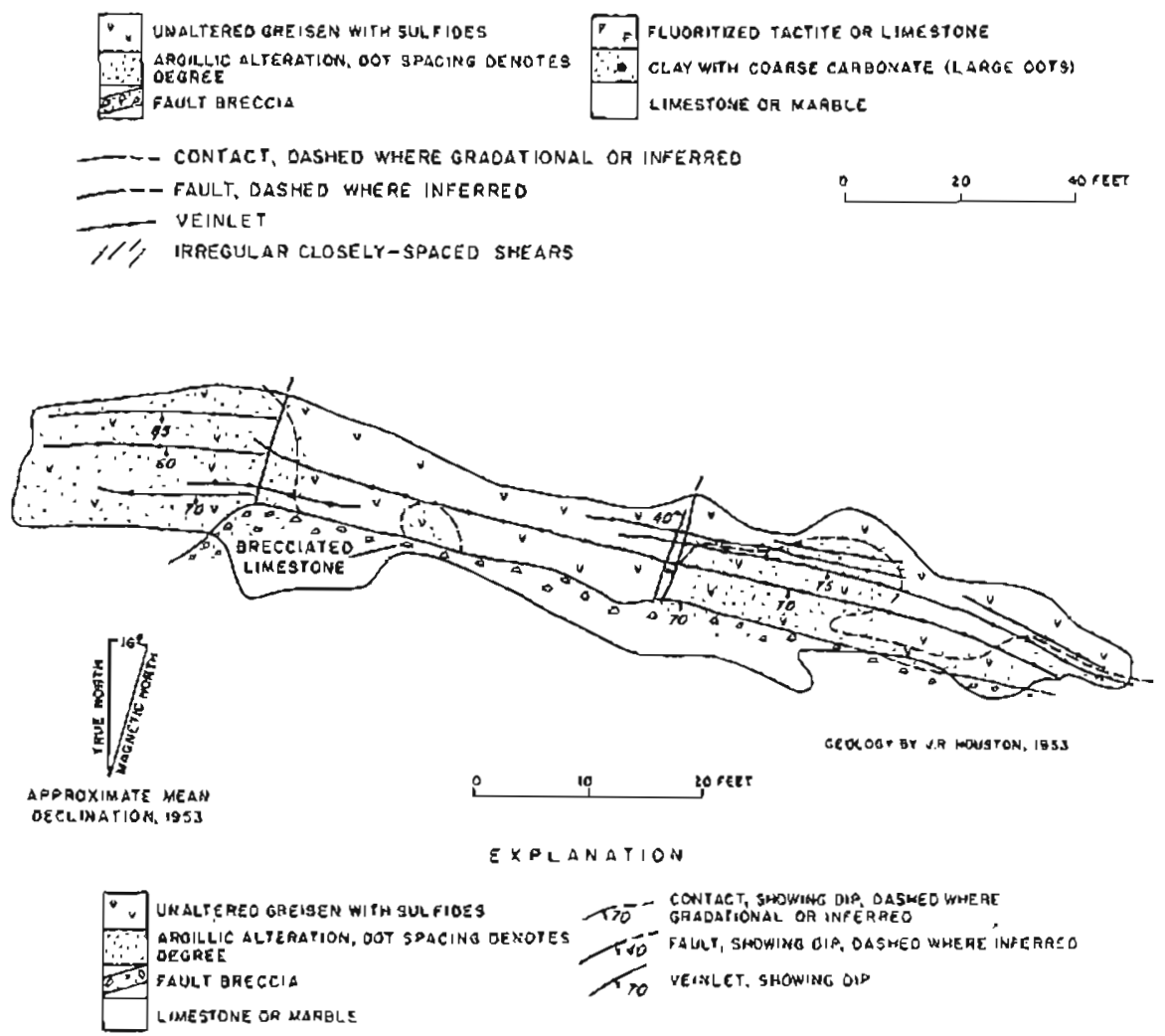

Frc. 9 (Upper). Geologic map of No. I adit showing argillic alteration.

FIG. 10 (Lower). Geologic map in $A-2-E$ stope showing argillic alteration unrelated to veinlets. 
and some of these sections show some disseminated ferroan sphalerite. No other metallic minerals are seen, and abundant assays from drill cores in this granite show that this freshest granite is almost barren of ore minerals, except where cut by veinlets.

The freshest granite is cut by thin veinlets that occupy joints and that contain ore and gangue minerals similar to those in veins in the limestone. Incipient argillization is shown by minute clots of clay minerals in the fine-

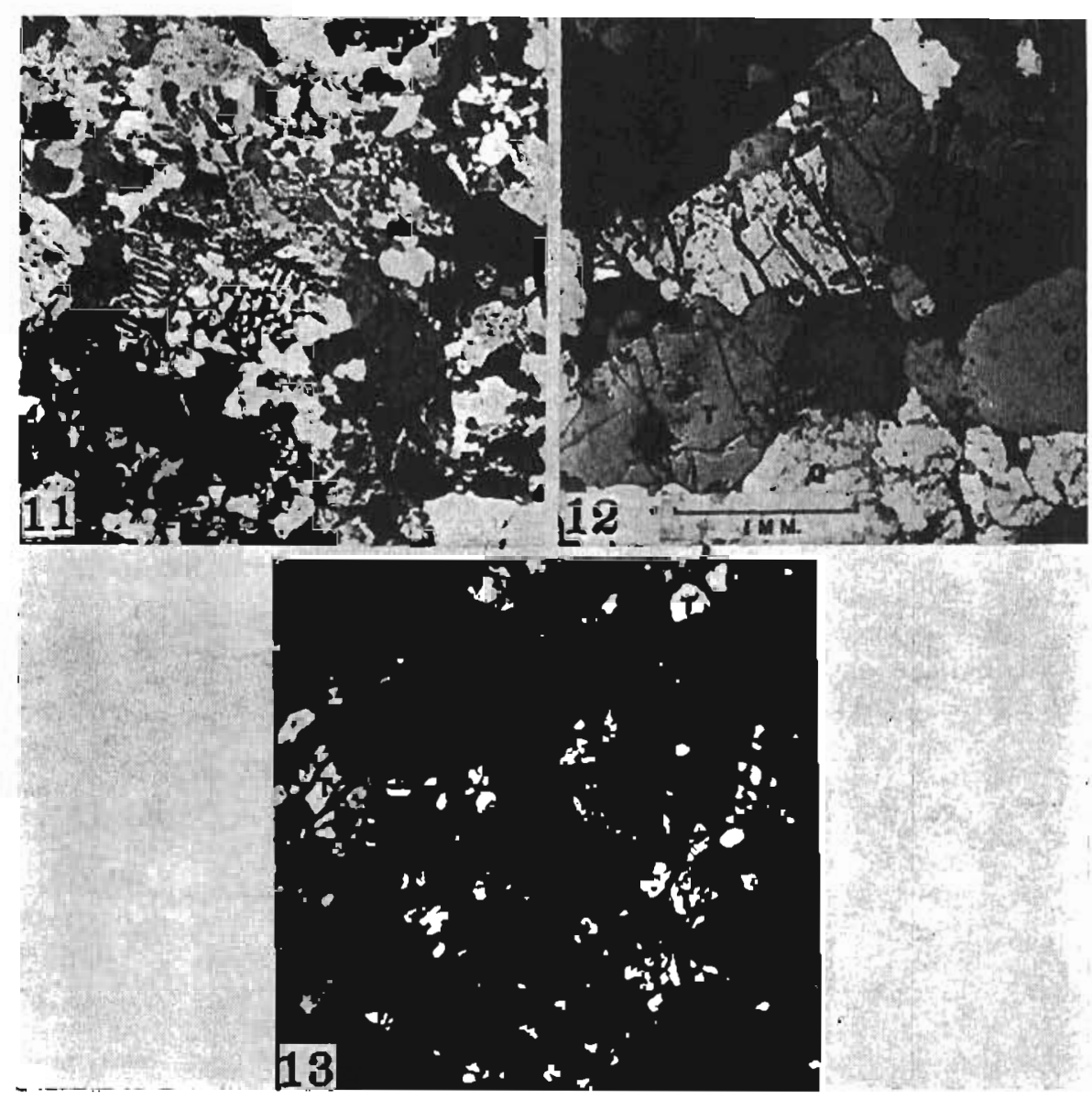

FIG. 11. Photomicrograph of freshest granitc; 195 crosscut west, 365 level. Note graplic texture of large quartz grains, twinned plagioclase, and abundant solid inclusions in all minerals.

FIG. 12. Photomicrograph of greisen from 365 level showing incipient argillization. Other minerals shown are pyrite, $P$, topaz, $T$, and quartz, $Q$. Note argillic alteration along cleavages in topaz. Partly crossed nicols.

Fic. 13. Photomicrograph of completely argillized greisen from 365 level showing residual topaz, $T$, encased in mass of clay minerals, $K$. Dark areas are fluorite and/or sulfide minerals. Crossed nicols. 
grained parts of the rock. The oligoclase and ortloclase, liowever, are relatively unargillized even though they contain alunulant minute snifi inclusions (Fig. 11).

Greisen and partly greisenized granite and rhyolite porphyry exist in all stages of argillization. With moderate argillization, the rocks are converted to a soit to friable mass of residual mineral graius encased in clays, or a mixture of clays and fine-grained mica. In general, the mica in samples of argillized granite or greisenized granite is fine-grained muscovite. but zinnwaldite is more common in samples of argillized rhyolite like rock or greisenized dike rock.

Stages in the conversion of greisen to clay are shown in Figures 12 and 13 . Argillization begins in the fine-grained parts, at grain boundaries, and along the cleavages in the topaz. With increasing argillization, both quartz and topaz are attacked, and the final product consists of clay minerals with a few scattered remnants of quartz and topaz and varinble amounts of fluorite. The iron sulfide minerais (pyrite and pyrrhotite) generally are lacking in such rock, but the cassiterite, arsenopvrite. and ferroan splalerite remain. Specks of limonite and limonite staining indicate that the original pyrite and purrhotite were altered to limonite.

The limestone is argillized at places to a mass of soit clay. Elsewhere, the limestone is hard to firm, and contains vugs lined with calcite, manganiierous calcite, and/or pale green fuorite. Dolomite was identifed by X-ray diffraction in some of the clays derived from limestone. The clays derived from limestone generally are darker than those derived from granite or greiser. Stratified clay seams and slump features are apparent locally in clays derived from limestone, and probably indicate solution stoping.

It is particularly noteworthy that myriad ore-bearing veinlets cut the marble exposed by mine openings, but that a great many of these veinlets do not contain clay minerals, again offering confirmatory evidence that the argillic alteration is not a halo about veins. Other veins do contain clay minerals, but evidence is presented later in this paper to show that such veins probably mark channels that were opened recurrently during both metallization and argillization.

Clay mineralogy.-Clay minerals were separated from 38 samples taken irom mine openings and diamond drill cores that explored the granite. The clay minerals were identified by X-ra! diffractometer after suitable treatment. Twenty-seven of the samples were separated and identified by John C. Hathaway and Carol C. Parker, and 11 were separated and identified by the writer.

The clay mineralogy is moderately complex. A regularly mixed-layered chlorite-montmorillonite occurs in 31 of 38 samples which represent altered limescone, granice. greisen, and probably tactite. Montmorillonite was identified in four samples. Hathaway and Parker state that the mixedlayered clay is chlorite and montmorilionite interlayered in 1:1 ratio. Such regularly interstratified clay has resisted attempts at synthesis, and is believed to represent alteration of chlorite or trioctahedral mica $(46)$.

Kaolinite and/or dickite was identifed in every sample, and forms the 


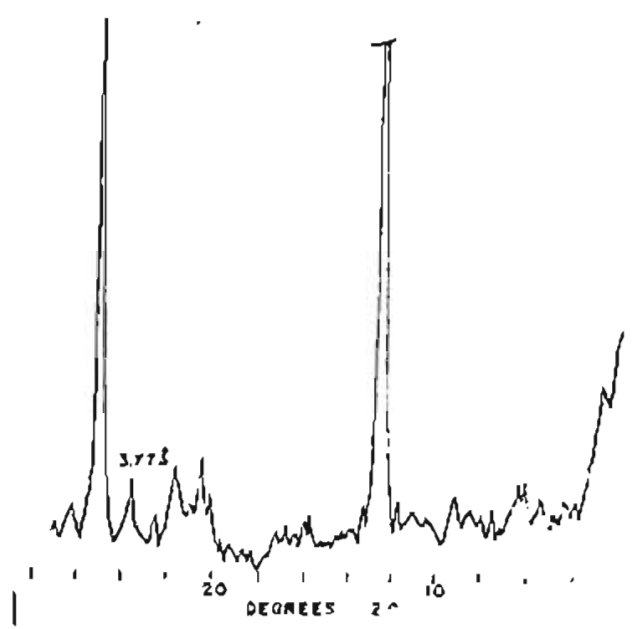

FIc. 14. Difiractometer pattern of unoriented, untreated dickite.

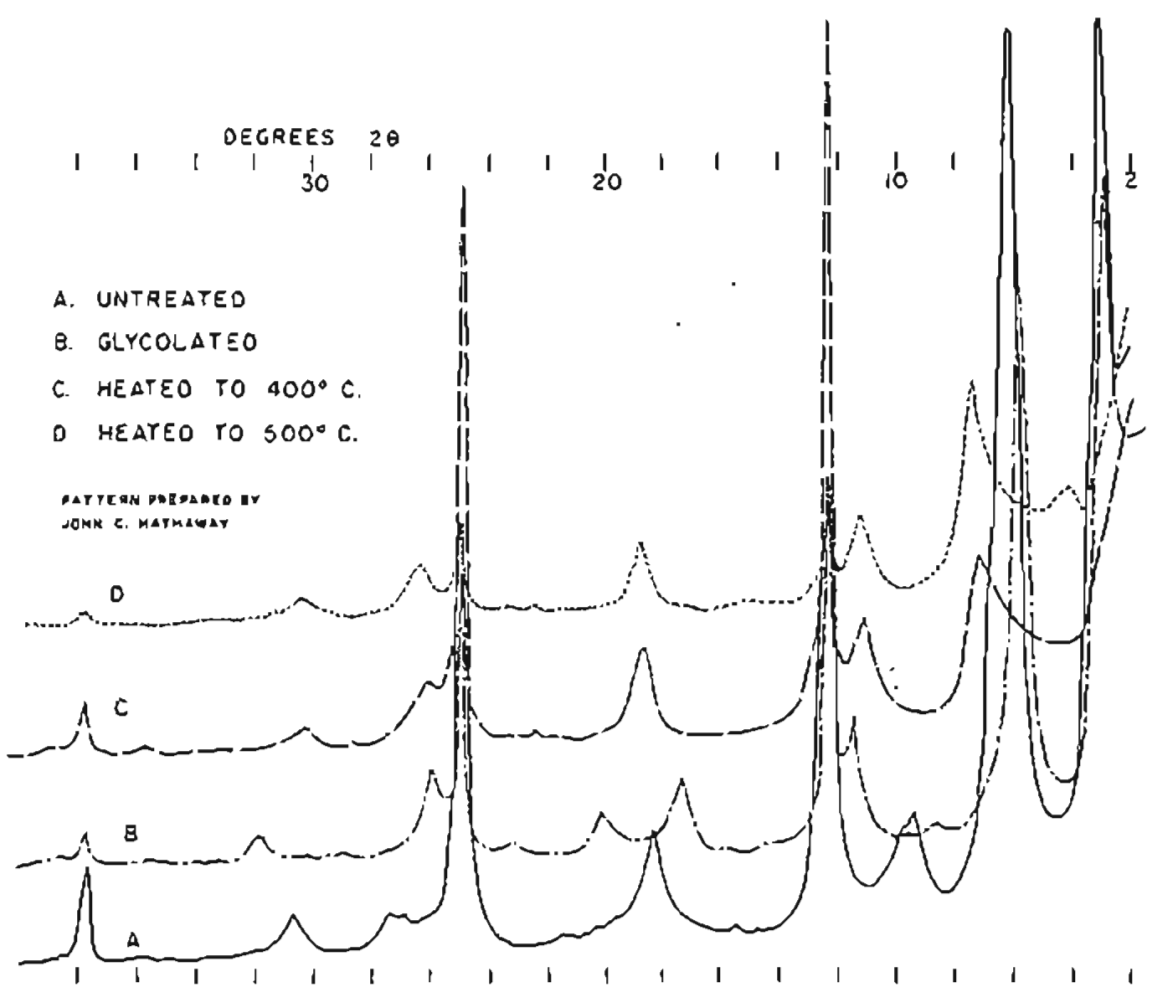

Fig. 15. Diftractometer patterns of oriented, treated kaolinite and mixed-lasered chlorite-montmorillonite. 
bulk of the clays. Dickite was identified positively in 14 samples representing argillized dike rock or greisen, limestone, and granite. It twas also identified in a clay veinlet in limestone.

Diffractometer patterns of the clays are shown in Figures 14 and 15 . The peak shown at $3.77 \mathrm{~A}$ on the dickite pattern is the main one that differentiates dickite from kaolinice. The curves for the mixed-layered chloritemontmorillonite are similar to those reported by Earley, Brindley, McVeagh, and Varden Huevel (15).

\section{Chemical Changes During Alleration}

Chemical analyses were made of 13 rocks trom the Lost River mine by P. L. D. Elmore, K. E. White, and S. D. Botts of the U. S. Geological Survey, using the rapid method (32). Fluorine was determined separately. Although chemical analyses that would have detected the minor constituents such as lead, zinc, tin, tungsten, and molybdenum would have been useful, the rapid analyses are believed to be sufficiently accurate to detect the major chemical changes that took place during greisenization and argillization. The analytical results are shown in Table 1 , and the composition of $100 \mathrm{cc}$ of rock is shown in Table 2. The gains and losses are shown graphically in Figures 16-19.

The method of computation used in these tables involves the conversion of weight percent of constituents to the composition of $100 \mathrm{cc}$ of rock through the use of bulk density (44). This method has inherent weaknesses, as pointed out by Poldervaart (44) and others, the major objection being that it assumes a constant volume during metasomatism. Cooper (11) recently has shown the feasibility of determining volume changes, however, where dependable thickness measurements can be obtained. Accurate information on volumetric change was not obtained at Lost River. Barth (4) has proposed an alternative scheme, which assumes a constant number of oxygen ions. Discussions by Brajnikov (5), Perrin (43), Eskola (17), and others show that no petrologic calculation can be made that is free of potential error. The evidence at Lost River indicates little volume change in the granite and dike rocks, but appreciable volume changes in the limestone, at least locally. The volume changes cannot be quantitatively assessed, however. The results shown in Figures 17-19 are based upon chemical changes in the granite, and are believed to represent real changes. It should be pointed out, however, that the slopes of the curves could be manipulated substantially by alternative calculations, e.g., the exclusion of water, sulfur, or fluorine. Figures 16 shows the positions of the analyzed rocks with respect to tresh granite, high-topaz greisen, and completely argillized granite.

Chemical Changes During Greisenisation.-Figure 17 depicts the chemical changes during conversion of granite to greisen containing progressively greater amounts of topaz. The underlined numbers below the vertical lines show the approximate amount of topaz in the rock. The rocks lie along the line between fresh granite and greisen that contains progressively larger amounts of topaz, as shown in Figure 16. 

TABLE 2

COMPOSITION OF 100 CC OF ROCKS. LOST RIVER MINE

\begin{tabular}{|c|c|c|c|c|c|c|c|c|c|c|}
\hline Oxide & I & 2 & 3 & 4 & $s$ & 6 & 7 & 8 & 9 & 10 \\
\hline 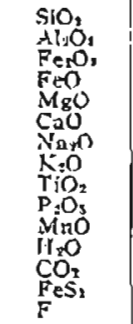 & $\begin{array}{r}105.535 \\
35.193 \\
.6211 \\
1.446 \\
.4114 \\
1.627 \\
8.956 \\
12.135 \\
.052 \\
.284 \\
3.021 \\
.181 \\
1.420\end{array}$ & $\begin{array}{r}206.250 \\
38.500 \\
1.375 \\
5.745 \\
1.100 \\
1.073 \\
3.025 \\
8.250 \\
.055 \\
.055 \\
1.265 \\
4.400 \\
.330 \\
5.885\end{array}$ & $\begin{array}{r}194.180 \\
45.2611 \\
.0011 \\
7.542 \\
+.904 \\
.518 \\
.876 \\
.175 \\
.058 \\
.058 \\
.550 \\
6.718 \\
.263 \\
20.148 \\
0.578\end{array}$ & $\begin{array}{r}194.86 .3 \\
54.444 \\
.000 \\
6.248 \\
.536 \\
10.115 \\
.148 \\
2.053 \\
.0011 \\
.030 \\
.476 \\
4.163 \\
.238 \\
9.223 \\
23.562\end{array}$ & $\begin{array}{r}185.380 \\
51.150 \\
.000 \\
14.2601 \\
.373 \\
.431 \\
.124 \\
.180 \\
.136 \\
.004 \\
.341 \\
1.841 \\
3.720 \\
35.030 \\
16.306\end{array}$ & 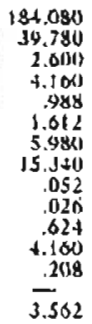 & $\begin{array}{r}72.560 \\
34.080) \\
.720 \\
4.080 \\
2.4110 \\
1.968 \\
1.032 \\
11.040 \\
.048 \\
.024 \\
1.176 \\
8.406 \\
.774 \\
-.656\end{array}$ & $\begin{array}{r}206.152 \\
+6.136 \\
1.460 \\
3.21 .2 \\
4.3817 \\
2.100 \\
.175 \\
4.964 \\
.030 \\
.004 \\
4.088 \\
12.264 \\
2.628 \\
7.123\end{array}$ & $\begin{array}{r}170.400 \\
30.720 \\
.720 \\
0.240 \\
5.1440 \\
2.352 \\
.888 \\
2.040 \\
.048 \\
.024 \\
.816 \\
17.280 \\
.624 \\
- \\
2.688\end{array}$ & $\begin{array}{r}110.453 \\
42.749 \\
2.387 \\
1.845 \\
211.181 \\
2.604 \\
.825 \\
1.049 \\
.043 \\
.0007 \\
.347 \\
30.597 \\
.347 \\
2.387\end{array}$ \\
\hline $\begin{array}{l}\operatorname{Sum}_{\text {ess }} O=F_{8} \\
\text { Corr. Sum }\end{array}$ & $\begin{array}{r}260.961 \\
.594 \\
260.307\end{array}$ & $\begin{array}{r}277.338 \\
2.475 \\
274.863\end{array}$ & $\begin{array}{r}291.036 \\
4.088 \\
280.948\end{array}$ & $\begin{array}{r}306.101 \\
9.818 \\
206.283\end{array}$ & $\begin{array}{r}309.938 \\
6.820 \\
303.118\end{array}$ & $\begin{array}{r}262.172 \\
1.508 \\
261.604\end{array}$ & $\begin{array}{r}242.928 \\
1.968 \\
240.960\end{array}$ & $\begin{array}{r}294.774 \\
2.920 \\
291.854\end{array}$ & $\begin{array}{r}240.481 \\
1.128 \\
239.353\end{array}$ & $\begin{array}{r}216.414 \\
.998 \\
215.416\end{array}$ \\
\hline
\end{tabular}

The analyses show significant changes. The oxides of potassium and sodium are removed rapidly with greisenization, reflecting the destruction of orthoclase and plagioclase feldspar, or its conversion to topaz, without fixation of $\mathrm{K}_{2} \mathrm{O}$ and $\mathrm{Na}_{2} \mathrm{O}$ in new minerals in the greisen. Silica rises sharply with initial greisenization (e.g., low-topaz greisen), and falls steadily as more topaz forms, as would be expected. The downward break in the silica curve coincides with the upward break in the curve for iron sulfide, which apparently marks the beginning of metallization. Alumina and fluorine rise steadily

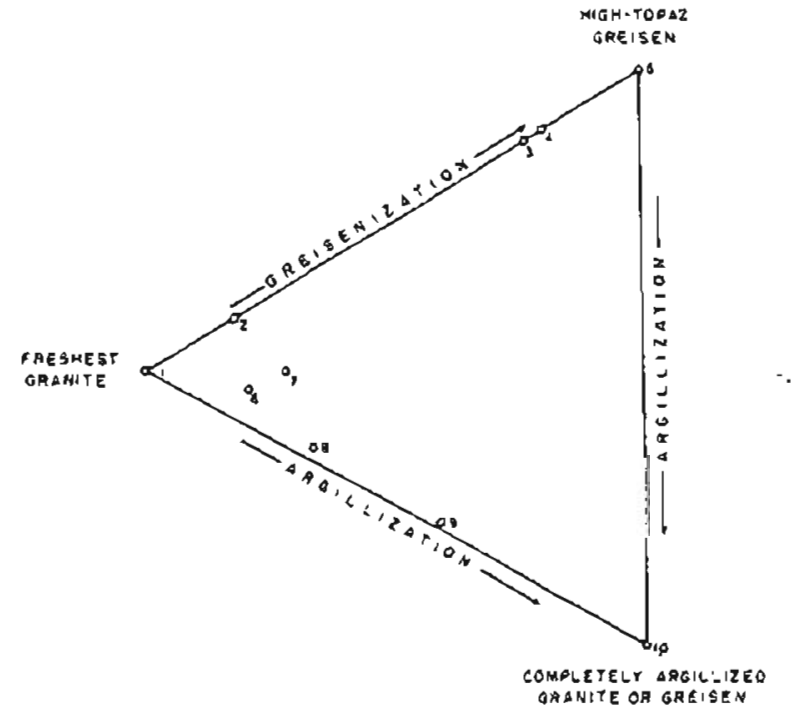

FIG, 16. Ditgram showing relative pusitiuns of rocks analyzed with respect to degree of alteration. 
as a direct consequence of the formation of high-alumina topaz at the expense of feldspars. Total iron, not shown as an individual line on the diagrams, increases through greisenization. The changes in the oxides of calcium, magnesium, and ferric iron are not large enough to be considered diagnostic, but trends probably are reflected.

Chemical changes involved in greisenization of granite near various tin deposits have been discussed by Vogt (62), Dalmer (13), and Cotton (12);

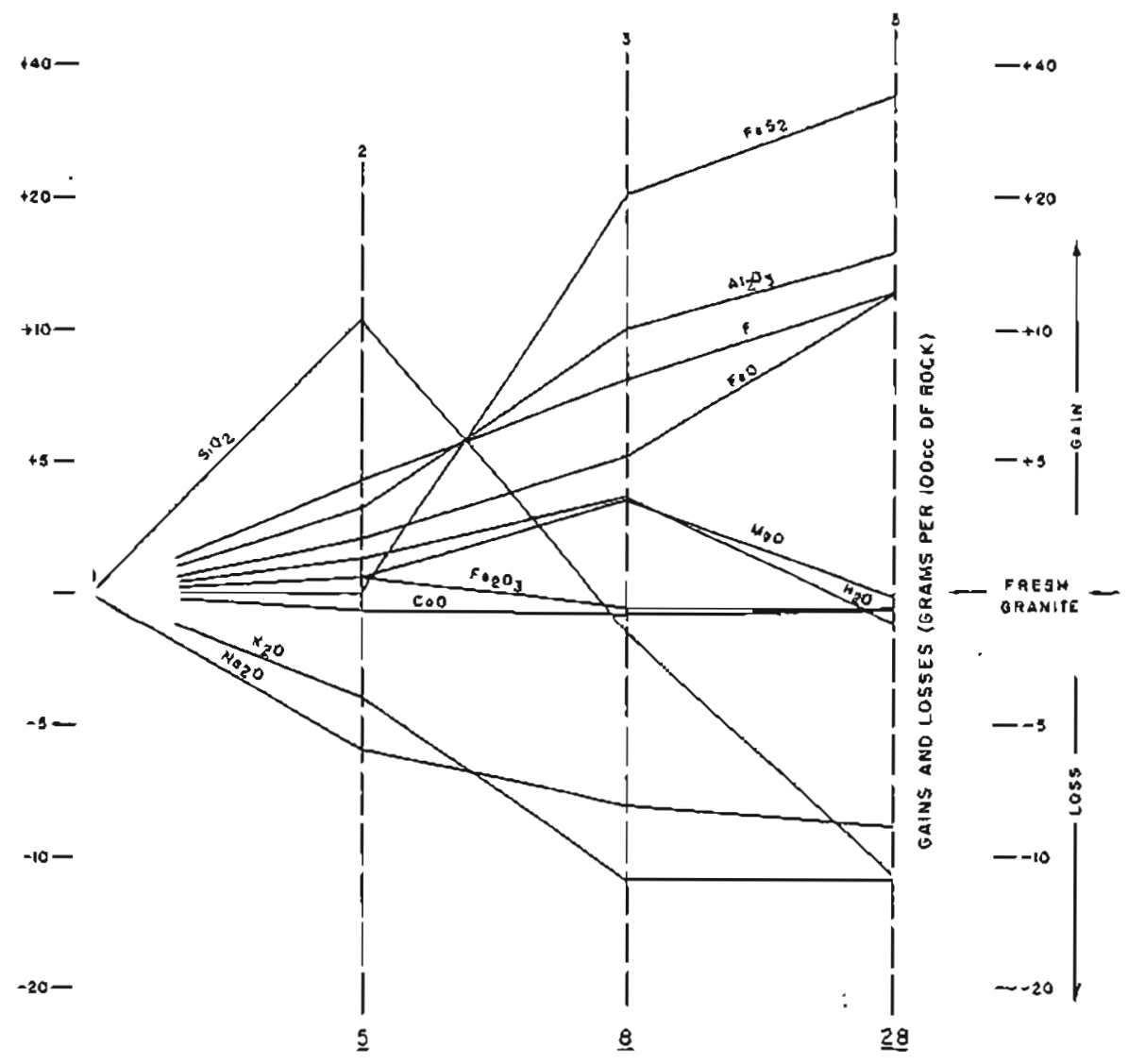

FrG. 17. Chemical changes during greisenization.

their results were summarized by Ferguson and Bateman (20). The chemical changes in converting granite at Lost River to greisen are compatible with changes observed eisewhere in regard to loss of the oxides of potassium and sodium, and gain of iron and florine. Alumina and silica, however, can be expected to show variable degrees of change depending entirely upon the role of topaz and mica in a greisen. In any greisen with a high percentage of topaz and a low percentage of mica formed at the expense of feldspar in a granite, 
alumina will increase and silica will decrease, for conversion of feldspar to topaz involves gain of alumina and decrease of silica. This is shown in Figure 17. Lindgren (36) pointed out in 1901 that greisenization does not necessarily imply addition of silica, which is borne out by the present study.

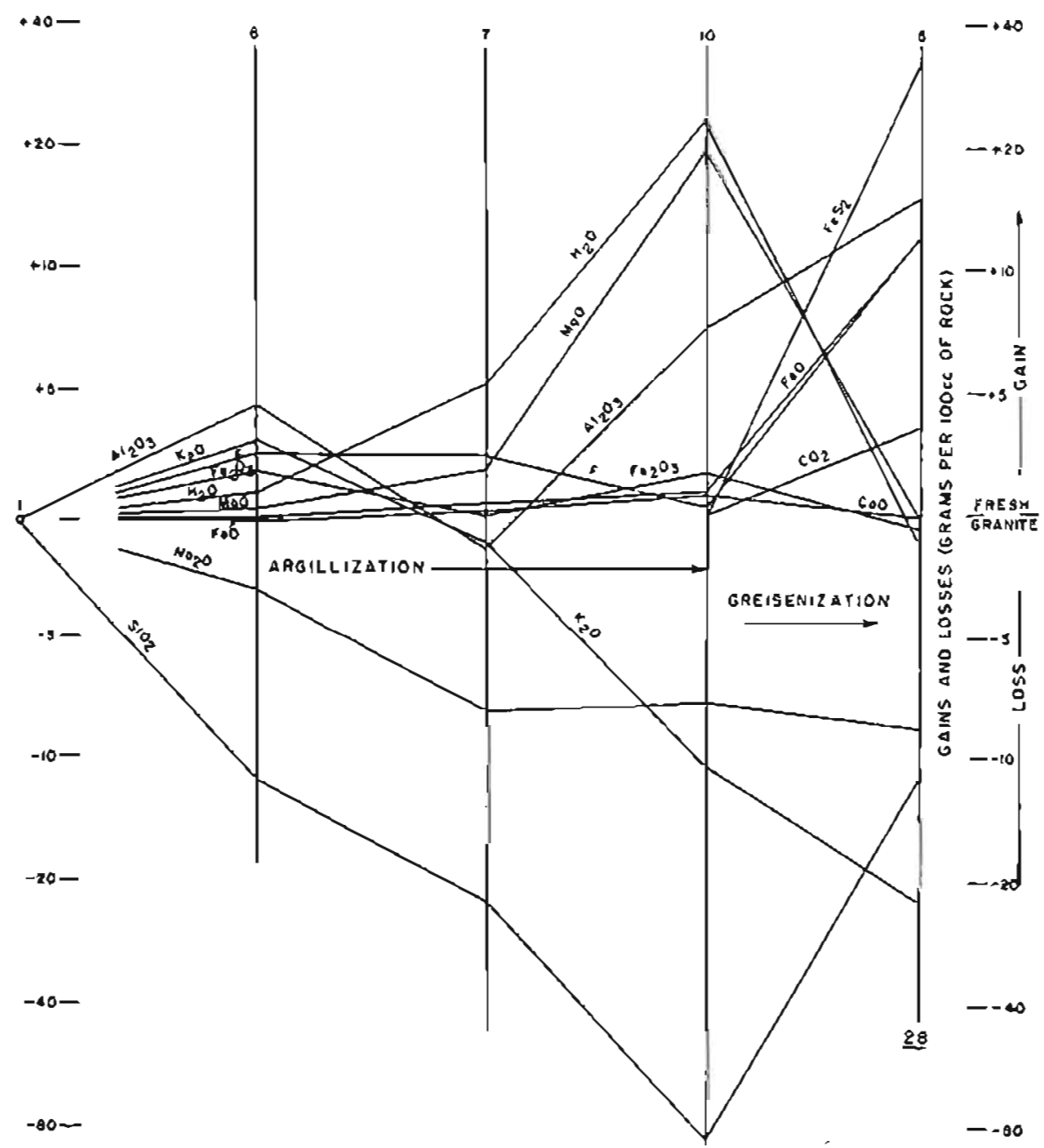

Fxc. 18. Chemical changes in argillization of partly greisenized granite.

Chemical Changes During Argillization.-The chemical changes involved in argillization of partly greisenized granite are shown in Figure 18, and in argillization of ungreisenized granite in Figure 19. The curves exhibit strong resemblances to those of Figure 17 for the oxides of potassium, sodium, and silicon. Silica is leached more strongly during argillization. Water increases 


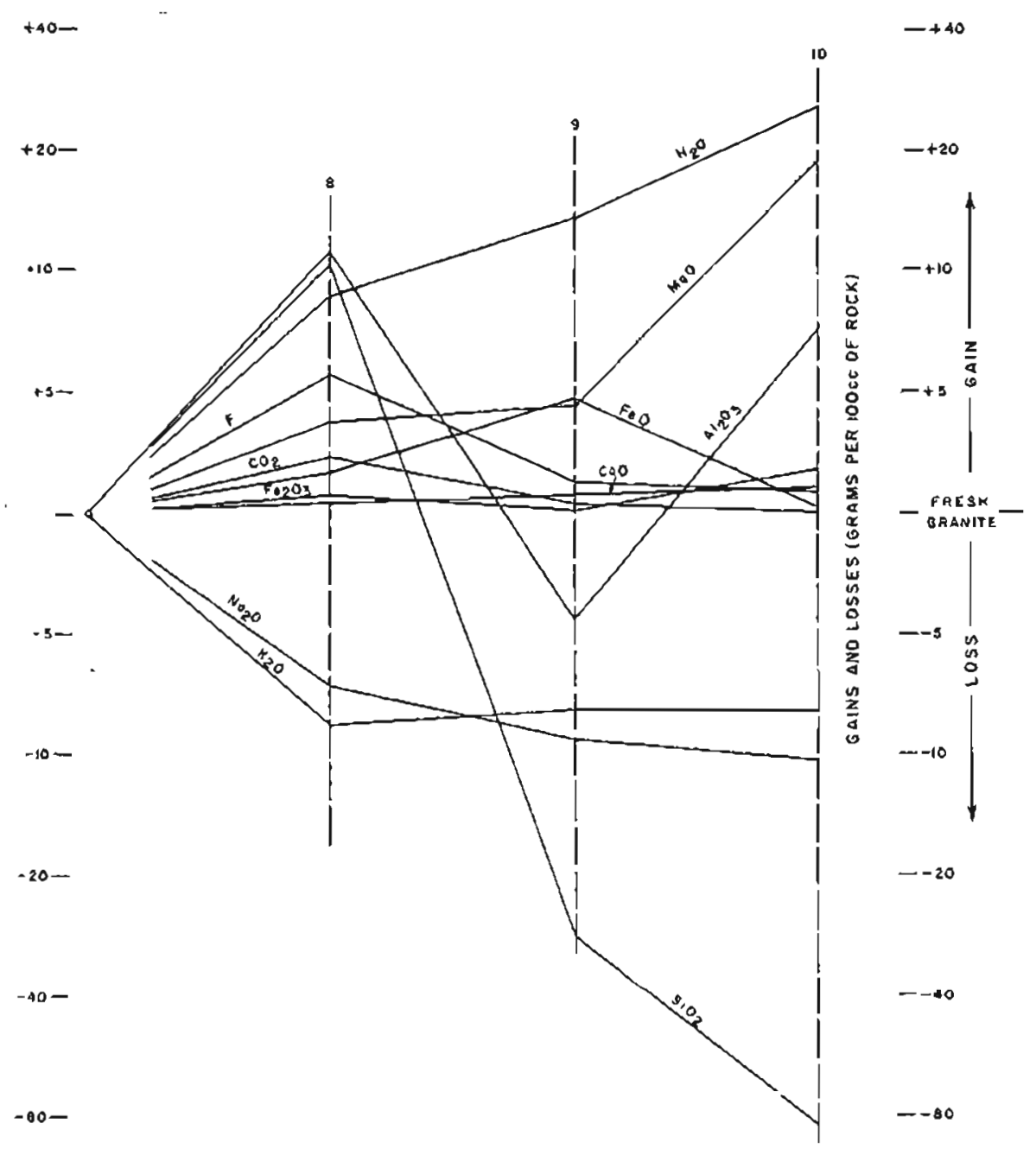

FIG. 19. Chemical changes in argillization of ungreisenized granite to faintly greisenized granite.

because of the hydrated clay minerals. The increase of magnesia probably reflects trapping of magnesium ions, derived from the limestone into which the granite is intrucled, by the mixed-layered chlorite-montmorillonite or in the dolomite associated with sone of the argillized granite. The absence of sulfur in argillized granite which was not strongly greisenized previously is notable (Table 1, Fig. 19), and offers confirmatory evidence that metallization and argillization were not contemporaneous. The final column in Figure 18 shows the chenical changes that would be required to convert completely argillized granite to greisen with a large percentage of topaz. 
The curves depicting chemical changes show that the oxides of potassium, sodium, and silicon behaved similarly during changes that would seem to reflect a substantial change in the fluids. For instance, the fluids responsible for metallization must have carried considerable fluorine and sulfur, yet silica and the alkali oxides behaved the same as during the argillic phase of alteration when fluorine and sulfur presumably were considerably reduced. The behavior of silica and the oxides of potassium and sodium would suggest contimed acid leaching, probably by carbonic acid, as Lemberg (34) has shown that topaz, normally a very resistant mineral, breaks down rapidly in carbonic acid.

\section{DISCUSSION}

\section{Hypogene Origin of Clays}

The main thesis of this paper, that argillization at Lost River is hypogene and postmineral, depends in large measure on the factors that establish the argillization as hypogene rather than supergene. Consequently, it is necessary to present that evidence here. The main points are:

(1) Supergene oxidation of sulfides at Lost River is slight even at the surface. Abundant primary sulfide minerals including pyritc and arsenopyrite are found at the surface in the Cassiterite dike and in myriad veinlets. Oxidation products of the ore minerals are known only in minor amounts.

(2) Weathering at Lost River is accomplished principally by frost action. Frost-riven fragments of dike rock containing fresh pyrite can be found at the surface.

(3) The argillized parts of the dikes are spatially associated with the parts that contain hypogene minerals, such as topaz, whereas pyrite is widespread in the dikes.

(4) The mine is within and beneath the permafrost, and the lower levels of the mine are at least 200 feet below the water table. The York Mountains were glaciated, and uplifted during the Pleistocene and Recent epochs (58), from which it is concluded that the deposit was continuously beneath the water table during any warm periods since late Pliocene. No evidence has been found to indicate that pre-Pleistocene weathering has survived to the present in the York Mountains.

(5) The amount of clay increases near the granite, which is below the water table in the lowest level of the mine. Sulfide minerals, however, are abundant throughout the mine.

(6) The large masses of clay in and near the granite are capped by marble and tactite, containing notable amounts of pyrite and other sulfide minetals, yet the tactite is not argillized except where cut by clay veinlets.

(7) Dickite is found throughout the mine, and dickite generally is lselieved to be nust commonly a prodluct of hydrothermal alteration (21).

(8) The breakdown of topaz suggests hydrothermal action by carbonic acill, as found by Lemberg (3t), and supported by Povarennykh (45).

These eight facts seen to the writer to rule out a supergene origin for the clays. 


\section{Megascopic Evidence for Post-mineral Age of Clays}

The post-mineral age of the clays is shown by petrographic evidence already presented. However, features of much larger scale were used initially to show a post-mineral age for the clays, and ofter conclusive proof. Some of these megascopic features are:

(1) Veins and veinlets witl no argillic envelope which transgress lithologic facies that grade from hard, gray sulfide-lsearing greisen through partly argillized greisen to completely argillized greisen (Figs. 9, 10). Many of these veinlets contain topaz, mica and ore minerals, and the silicate minerais in the vein are fresin in the fresh greisen, and argillized in the argillized greisen, showing that argillization advanced "endwise" on the vein, or upward on certain parts of the vein only.

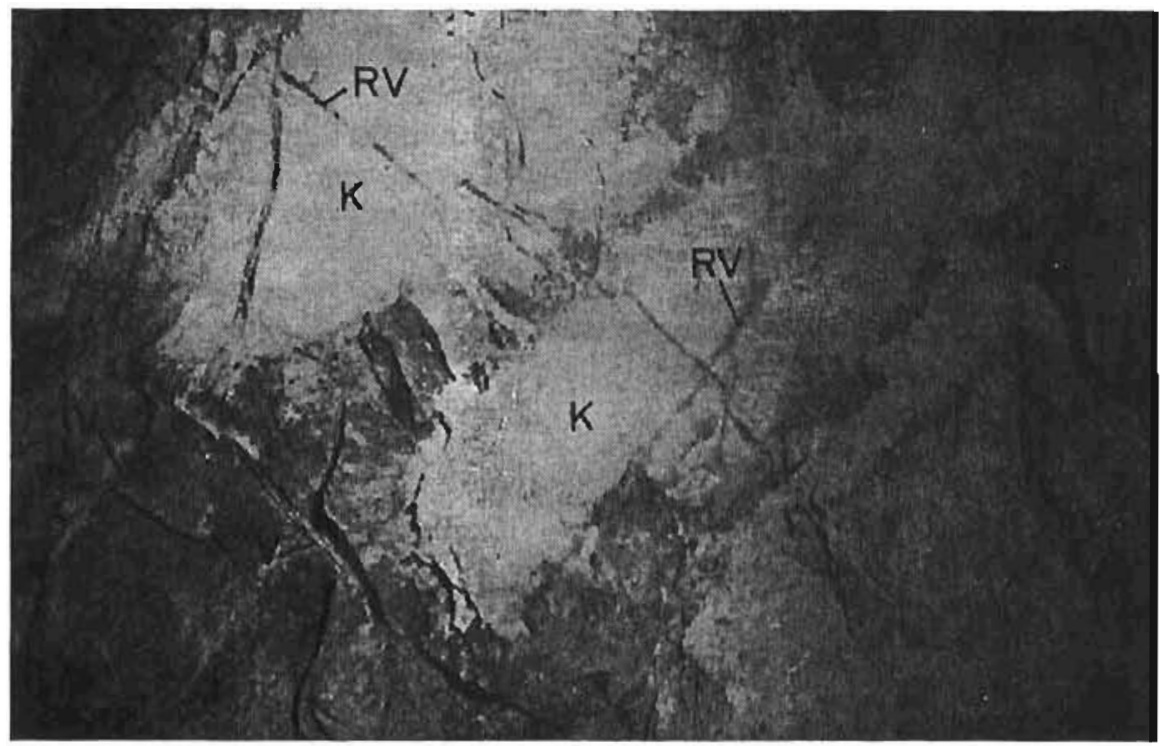

FIc. 20. Photograph of solid kaolinite, $\mathrm{K}$, developing in the Cassiterite dike, No. 3 adit level. Note small, thin veinlets, $V$, along joints in lower leit. Vejnlets with dituse outline but with same orientation are retained in clay as relict structures, RV, in solid clay. Veinlets are approximately 3 -inch wide.

(2) Completely argillized dike rock has been found with relict veinlets containing cassiterite, arsenopyrite, ferroan sphalerite, wolframite and fluorite. The veins are oriented the same as those found in adjoining unargillized rock that contain mica, topaz, quartz, and tourmaline in addition (Fig. 20).

(3) Ore minerals are lacking in nuch of the granite that is highly argillized, yet ore minerals are everywhere found in unaltered greisen or in argillized rock containing residual topaz.

(4) Large volumes of the Cassiterite dike, the granite, and the limestone near the granite, consist almost entirely of massive clays that contain cassiterite 
The curves depicting chemical changes show that the oxides of potassium, sodium, and silicon beliaved similarly during clanges that would seem to reflect a substantial change in the fuids. For instance, the fluids responsible for netallization must have carried considerable fluorine and sulfur, yet silica and the alkali oxides behaved the same as during the argillic phase of alteration when fluorine and suifur presumably were considerably reduced. The behavior of silicn and the oxides of potassium and sodium would suggest contimued acirl leaching, probably by carbonic acid, as Lemberg (34) has shown that ropaz, normally a very resistant mineral, breaks down rapiclly in carbonic acicl.

\section{DISCUSSION}

\section{Hypogene Origin of Clays}

The main thesis of this paper, that argillization at Lost River is hypogene and postmineral, depends in large measure on the factors that establish the argillization as hypogene rather than supergene. Consequently, it is necessary 10 present that evidence here. The main points are:

(1) Supergene oxidation of sulfides at Lost River is slight even at the surface. Abundant primary sulfide minerals including pyrite and arsenopyrite are found at the surface in the Cassiterite dike and in myriad veinlets. Oxidation products of the ore minerals are known only in minor amounts.

(2) Weathering at Lost River is accomplished principally by frost action. Frost-riven iragments of dike rock containing fresh pyrite can be found at the surface.

(3) The argillized parts of the dilkes are spatially associated with the parts that contain hypogene minerals, such as topaz, whereas pyrite is widespread in the dikes.

(4) The mine is within and beneath the permafrost, and the lower levels of the mine are at least 200 feet below the water table. The York Mountains were glaciated, and uplifted during the Pleistocene and Recent epochs (58), from which it is concluded that the deposit was continuously beneath the water table during any warm periods since late Pliocene. No evidence has been found to indicate that pre-Pleistocene weathering has survived to the present in the York Mountains.

(5) The amount of clay increases near the grauite, which is below the water table in the lowest level of the mine. Sulfide minerals, however, are abundant throughout the nine.

(6) The large masses of clay in and near the granite are capped by marble and inctite. containing tontable announts of pyrite and other sulfide minerals, let the tactite is not argillized except where cut by clay veinlets.

(7) Dickite is round throughout the mine, and dickite generally is believed (11 be mest crimmonly a prochuct of hydrothermal alteration (21).

(8) The breakclown of topaz suggests hydrothermal action by carbonic acid. als found by Lemiery (34), and supported by Povarennykh (45).

These eight jacts seem to the writer to rule out a supergene origin for the clays. 
in economic amounts. The solid white clay at the east end of No. 1 adit (Fig. 9) contains an average of 2.5 percent of tin that occurs disseminated in the clay. This argillized rock grades laterally into greisen containing tin in similar amounts but with abundant sulfide ore minerals. Such relations clearly show that the argillic alteration is later than cassiterite and greisenization.

(5) Small fragments of slightly argillized greisen are found isolated in solid clay, a relation that is common in the clay pits of Cornwall (61), where kaolinization is now considered to be hypogene $(28,6,27)$. This relation can be explained reasonably only by assuming that the greisen fragments are residual. The residual greisen fragments at Lost River contain cassiterite and sulfide ore minerals, which shows clearly that cassiterite and sulfides predated argillic alteration.

(6) Veins with a center "rib" of fluorite encased in clay are found in limestone in many parts of the mine. Fluorite has spread into the walls beyond the clay. The center rib of fluorite is cut by clay-filled fractures. In near proximity are other fluorite veins with unargillized walls, again indicating some type of disparity between veins and argillic alteration.

(7) Some veins in limestone have clay-fluorite centers and walls of banced tourmaline-fluorite-sulfide rock, but are rare. Small clay veinlets branch from the centers oi the veins and crosscut the banded walls. The clay is a mixture of mixed-layered chlorite-montmorillonite and knolinite. The clay in such veins obviously is later than the toumaline and the ore minerals.

The veins described under 6 and 7 above are believed to represent older veins that were reopened during the argitlic phase of alteration, or that remained open until temperatures dropped to the point where clay minerals were stable.

\section{Temperatures During Metallization and Argillization}

Tentperalures Deduced from Ore Minerals and Greisen.-Direct evidence of the actual temperature of ore deposition at Lost River is fornd from the iron-zinc ratios in sphalerite, according to Kullerud's method (33). The brilliant-black ferroan sphalerite is very common in the granite and in veinlets in the Cassiterite dike. R. G. Coleman, of the U. S. Geological Survey, reports an iron content of 11.7 weight percent in a sample of a single large and pure crystal that came from the 365 level. Semiquantitative spectographic analyses of two other specimens of single pure crystals showed iron in the range of 10-15 percent. The minimum temperature of deposition of the sphalerite, according to Kulferud's curves, is about $425^{\circ} \mathrm{C}$, with a maximum temperature that could range up to $740^{\circ} \mathrm{C}$. Abundant pyrite is associated with the sphalerite, but pyrrhotite is rarer, being found in quantity only in sulfide concentrates from the cleaner circuit in the mill flotation plant. Thus, in the absence of dependable data showing coexistence of sphalerite and pyrrhotite, the maximum temperature of deposition cannot be stated certainly. The minimum temperature of deposition, however, may be taken as $425^{\circ} \mathrm{C}$ without pressure correction.

Deductive evidence of the temperature of ore deposition is gained from a 
consirleration of the stability range of topaz, the ubiquitous associate of ore in greisen at Lost River. Topaz has heen synthesized by Daubrée (14), Coes (10). and Michel-Lévy and Myart (38): Daulbrée hy the action of steam on tin fluoride, and the other two hy use of the autoclave. Coes reports a temperature of formation that ranges hetween $600-900^{\circ} \mathrm{C}$, and Michel-Lévy and Wyart report synthesis at $500^{\circ} \mathrm{C}$ and a pressure of $4,000 \mathrm{~kg} / \mathrm{cm}^{2}$. At $455^{\circ} \mathrm{C}$ no topaz formed.

Tourmaline is found sparingly at Lost River in the Cassiterite dike, and in veinlets in the marble. It is less abundant in the granite, but it has been found. Tourmaline has been s!nthesized by Frondel, Hurlbut and Collette (22), and by 5 mith (56), at temperatures between $400-500^{\circ} \mathrm{C}$, although neither state the upper stahility range. Smith suggests a relatively restricted $\mathrm{pH}$ range for the tourmaline he synthesized, generally on the alkaline side but carrying over into the mildly acid range with increasing water. However, tourmaline grows authigenically (59), and therefore cannot be used as a decisive temperature indicator. although laboratory experiments suggest its hudrothermal formation would require a temperature of $400-500^{\circ} \mathrm{C}$.

Cassiterite is of little value in cletermining the temperature of ore deposition. owing to the wicle range in its temperature of formation, from surface water (wood tin) to typical tin-tungsten veins of hypothermal origin (3). Cassiterite has been synthesized by Smith (56) from room temperatures to $450^{\circ} \mathrm{C}$, but the upper stability range was not determined.

From the direct and deductive evidence, it is believed that the temperature dluring greisenization and introduction of the ore minerals was at least $425^{\circ} \mathrm{C}$, and probably was not below $500^{\circ} \mathrm{C}$. the mininum temperature reported for formation of topaz. The maximum temperature of deposition could reach $740^{\circ} \mathrm{C}$.

Temperatures Deduced from Clay Minerals.-Clay minerals have been synthesized in the laboratory by numerous workers. One fact of paramount importance to this paper, which energes from experimental data, is the relatively constant upper stability limit of any clay mineral in the various systems studied, a limit that falls between 400 and $480^{\circ} \mathrm{C}$. Roy and Osborne (47) report that kaolinite, hallnysite, nacrite, and dickite decompose at $405^{\circ} \mathrm{C}$, and 10,000 psi water pressure, and alunzinum montmorillonite at $420^{\circ} \mathrm{C}$. Varying the water pressure from 2,500 to 25,000 psi did not alter the deconposition temperature more than 10 degrees. Roy and Roy (48) showed that in a system containing magnesium, montmorillonite appeared at $480^{\circ} \mathrm{C}$. downward. Noll (41) in pressure bomb runs at $500^{\circ} \mathrm{C}$. found pyrophyllite to be the stable phase, whereas some kaolinite formed at $400^{\circ} \mathrm{C}$. Sand, Roy, and Oshorn (50) show a maximum decomposition temperature of $450^{\circ} \mathrm{C}$ for soclicm-montmorillonite.

From the above it is seen that the stability ranges of the minerals formed during greisenization and metallization, particularly topaz, are either above or in the uppermost part of the stability range of the clay minerals. The conclusion based upon mapping - that the metallization preceded the argillization-is completely compatible with laboratory data. The literature demonstrates great complexit! of mineral assemblages with differing chemical 
environments such as $\mathrm{pH}$ ( $\mathrm{H}^{+}$ion concentration), $\mathrm{K}^{+}$concentration, etc., but irrespective of chemical environment. no clay minerals were ever formed in laboratory experiments ahove the temperature limits quoted above. The writer believes that this fact has not received its proper consicleration by many writers who discuss argillic alteration. Ores deposited even in the temperature range between $350-400^{\circ} \mathrm{C}$ may be expected to show complexity of associated argillic alteration proclucts that may be a direct consequence of temperature differences rather than of changes in the mineralizing fuids.

Temperatures of Deposition of Tin Ores.-Sinith (54) tested samples of Cornish ore hy use of the decrepitation method. and found a temperature of formation in the range $265^{\circ}-390^{\circ}$ when correcterl to a depth of hurial of two miles. On this basis, Smitl questions the existence of all pneumatolytic deposits. Hosking (27) apparently accepts Smith's conclusions as valid for the entire Cornwall district. In view of the indicated temperature of deposition of the Lost River ores, a supercritical gaseous phase is indicated. even though this gas may have been dense.

The writer thinks that the temperature of formation of cassiterite and other minerals from the Cornwall district as reported by Smith probably are in error, and should not be consiclered as representative of the temperatures of formation of deposits of cassiterite in greisens. The Lost River deposit is typical of deposits known the world over. and the temperature of deposition at Lost River uncloubtedly was alonve that reported hy Snith for the Cornwall deposits. The writer's investigations support the opinion long held by geologists that the tin cleposits associated with granite plutons are formed at very high temperatures in the range of the "pneunatolytic" stage. The temperatures stated by Ahifeld (1) for the deposition of the Uncia-Llallagua cleposits in Bolivia seem realistic. Ahlfeld describes the following stages: (1) a high temperature, pneumatolytic phase with introduction of cassiterite and tourmaline; (2) an intermediate phase at a temperature of over $400^{\circ} \mathrm{C}$, and (3) a hydrothermal, low-temperature phase. The Lost River deposit would fall into Ahlelel's initial high-temperature, pneumatolytic phase.

Edwards and Lyon (16) have determined the temperature of deposition of sphalerite at the Aherfoyle tin minc, Tasmania. They record a temperature of deposition of "alont $600^{\circ} \mathrm{C}$." The relations they describe between ore minerals are very similar to those at Lost River, with cassiterite and wolframite preceding the sulficles. They do not record argillic alteration associated with the ore deposits.

\section{CHEMISTRY OF SOLUTIONS DURING ARGILLIC ALTERATION}

A complete discussion of the chemistry of the solutions that argillized the rock at Lost River is beyond both the scope of this paper and the writer's conpetence. A fell remarks, however, seem in order owing to the fact that topaz in large amounts was altered to clay.

Many writers have suggested that an acid environment contributes to the formation of kaolinite $(23,26,30)$; Smith (54) synthesized cassiterite from alkaline solutions, and conclucled that cassiterite possibly is deposited from 
acid gaseous solutions in near-surface environments and from aikaline solutions under deep-seated conditions,

The work of Lemberg (34) and Povarennykh (45) that demonstrates the instability of topaz in hypogene solutions containing carbonic acid or $\mathrm{Ca}^{\text {tw }}$ ion may help explain the destruction of topaz at Lost River and thus give information on the alkaline-acid relations. During greisenization and metallization, a supercritical phase was involved, which was high in fluorine, but low in $\mathrm{Ca}^{*+}$ ion. As temperatures fell, a hydrothermal phase developed that was richer in carbonic acid. The topaz, normally a very resistant mineral, formed during the initial acid stage, but broke down rapidly in the carbonic acid environment, thus hastening the argillization of the greisen, according to the equation shown below :

$$
\begin{gathered}
\text { copaz }+ \text { quartz }+ \text { water }+ \text { limestone } \rightarrow \text { kaolinite }+ \text { fuorlte }+\begin{array}{c}
\text { carbonic } \\
\text { acid }
\end{array} \\
(\mathrm{Al}, \mathrm{F})_{2} \mathrm{SlO}_{2}+\mathrm{SiO}_{2}+3 \mathrm{H}_{2} \mathrm{O}+\mathrm{CaCO}_{3} \rightarrow \mathrm{Al}_{2} \mathrm{Si}_{2} \mathrm{O}_{6}(\mathrm{OH})_{4}+\mathrm{CaF}_{3}+\mathrm{H}_{2} \mathrm{CO}_{3}
\end{gathered}
$$

Silica Behavior. - The behavior of silica is noteworthy, for silica declined through greisenization and argillization. Obviously the mineralizing flujds could not have been saturated in silica, and the quartz veins seen on the surface (Fig. 2) could have received their quartz from the alteration of the wall rocks below rather than from a magmatic silica-bearing fluid. Knopf (32) suggested such an origin for the silica in the veins of the Mother Lode system in California.

Quartz veins are relatively scarce in the underground workings at Lost River. Only two veins in which the gangue is predominantly quartz were found, one on the No. I level that contained cassiterite, arsenopyrite, and other sulfide minerals, and one on the 365-level containing arsenopyrite, woliramite, and cassiterite plus minor other minerals. On the suriace, however, quartz veinlets are relatively common, many of them being very rich in cassiterite (P. L. Killeen, personal communication). This distribution of quartz veins may reflect transition to pegmatite type of mineralization by a hydrothermal phase at some distance away from a gaseous phase which was above the critical temperature of water.

During argillization large amounts of silica were removed from greisen and granite. This gave rise to an interesting relationship in which a quartz vein containing cassiterite, woliramite and arsenopyrite that cuts greisen can be traced into moderately argillized rocks (vein A in Fig. 9). In this case, if only the section of the vein in the argillized rock were disclosed by mine workings, the quartz vein would appear to be later than the argillic alteration because of its apparent crosscutting relation. The quartz vein persisted in the argillized rock because of its quartz gangue, which could not be completely removed during argillic aiteration. In considering highly argillized rocks, this writer would have reservations in assigning a post-argillic or even a contemporaneous age to quartz veinlets enclosed totally in such argillized rock. Quartz veins certainly persisted well in the argillized rock

\footnotetext{
1 Kaolinite formula as suggested by Dr. H. S. Yoder of the Geophysical Laboratory of the Carnegie Institute.
} 
at Lost River. Schwartz (51) shows a photograph of an argillized rock from Morenci pit, Arizona, in which quartz veins apparently cut a highly argillized rack. If this specimen had come from the Lost River mine, the quartz vein would be pre-argillic. Kerr (30) describes alteration at Santa Rita, New Mexico, in which "late" quartz veins cut highly argillized rock. The writer finds it difficult to imagine how a rock consisting essentially of solid clay presumably saturated with water at high temperature can be fractured and veined with quartz veins. If kaolinization were being effected at the same time, the solutions that were filling the quartz vein would simultaneously be abstracting silica from the wall rock being argillized. At Lost River, pervasive argillization invaded veined rock, and in two places left oider quartz veins that contained ore minerals as relicts in the argillized rock.

\section{CONCLUSIONS}

1. Cassiterite at Lost River was deposited concomitantly with topaz, which indicates a temperature of deposition of at least $500^{\circ} \mathrm{C}$. Ferroan sphalerite was deposited above a temperature of $425^{\circ} \mathrm{C}$. These temperatures are within the range of temperatures measured at fumaroles depositing metals (9).

2. Argillic alteration, although closely related in time to ore deposition, was not directly related to ore, but rather to falling temperature. This concept is by no means new insofar as general thought is concerned, but the writer feels that it is worthwhile emphasizing the role of temperature in regulating argillic alteration associated with ore deposits. There is need for more information of actual temperature of deposition of ore with associated argillic alteration, by use of geologic thermometry, before the time relations between argillic alteration and mineralization can be stated with any degree of certainty.

3. Argillic alteration at Lost River cannot be used as a guide to the immediate proximity of ore, although it remains a useful regional criteria. Certainly widespread argillic alteration should be a very encouraging sign in this region, for it may point to a previous, higher-temperature cassiteritedepositing phase, but exploration of highly argillized areas may not necessarily outline ore.

\section{ACKNOWLEDGMENTS}

The writer is indebted to many members of the U. S. Geological Survey who contributed work incorporated in a forthcoming Geological Survey publication that led to the present paper. Most determinations of clay minerals were made by John C. Hathaway and Carol C. Parker; a few were reported and identified by the writer. J. R. Houston and G. Donald Eberlein contributed to the detailed underground mapping. The help of these workers is gratefully acknowledged here, and their individual contributions to the understanding of the mine geology will appear in the forthcoming U. S Geological Survey report.

The paper was reviewed by T. S. Lovering, E. M. MacKevett, Jr., and 
H. R. Cornwall, and the writer is indebted to them for helpful suggestions. The ideas and conclusions expressed herein are the responsibility of the writer. This paper is lyy mo means intended to be a full discussion of a very complex mine.

\section{U. S. Geolocitcal Survey, Menlo Park, California, Feb. 25, 1960}

\section{REFERENCES}

1. Ahifeld, F., 1929, Die zinnergrube Uncia-Liallagua, Bolivia: Metall, u Erz., 26 (14) p. $349-354$.

2. Anderson, C. A., 1950, Atteration and metallization in the Bagdad porphyry copper deposit, A rizona: ECoN. Geol., v. 45, p. 609-628.

3. Barsukov, V., 1953, On the modes oi transport of tin in bydrothermal solution: Akedemiya Nauk, SSSR, Doklady 93, p. $106 \hat{5}-1068$.

4. Barth, T. M. F., 1948, Oxygen in rocks, a basis for petrograpbic caiculations: Jour. Gcol. v. 56 , p. $50-60$.

5. Brajnikov, B., 1949, Les rapports aumériques et volumigues de l'oxygene dans les minéraux et les roches: Instituto de Tecnologia Indusrial, Minas Gerais, Bol. 8, 1949.

6. Brown, L. G., 1953, Geological aspects of the Saint Austell granite; Clay Minerais Bull, v. 2, no. 9, 0. 17-21.

7. Burbank, W. S., 1950, Probiems of wall rock alteration in shallow volcanic environments: Colorado School of Mines Quarterly, v. 45, p. 286-326.

8. Caillére, S., Oberlin, A., and Hénln, S. 1954, Electron microscope study of sevecal phyllitic silicates synthesized at low temperatures: Clay Minerals Bull., 2 (12), p. 146-156.

9. Clark, F. W., 1924, The data of Geochemistry, 5th Ed., Chap. 8, Volcanic gases and sublimates: U. S. Geol. Survey Bull. 700, 261-292.

10. Coes, L., 1956, as reported by Roy, Rustum, and Tuttle, D. F, in Pliysics and Chemistry of the Earth: McGraw-Hill Book Co., New York, N. Y., p. 146.

11. Cooper, John R., 1957, Metamorphism and volunie losses in carbonate rocks near Johnsols Canip, Cochise County, Arizona: Geol. Soc. America Bull., v. 68, no. 5, p. 577-610.

12. Cotton, L. A., 1909, Metasomatic processes in a fissure vein from New England: Linnean Soc. New South Wales Proc., v. 34, p. 220-232.

13. Dalmer, K., 1894. Der Altenberger-Graupener Zinnerzlnger-stattendistrikt: Zeitschr. prakt. Geologie, p. 313-322.

14. Danbrée, A., 1849, Annaies des Winés. th Ser., v. 15, p. 29

15. Earles, J. W., Brindley, G. W., MIcVeagh, W. J., and Vanden Huevel, R. C., 1956, A regularly interstratified montmorillonite-chlorite: Ars. Mincralogist, v. 41. D. 258-567.

16. Edwards, A. B., and Lyon, R. J. P.. 1957, Mineralization at Aberfoyle tin inine, Rossarden, Tasmania : Australasian Inst. Alin. Metallurgy Proc. No. 181, p. 93-145.

17. Eskala, Pentti, 1954, A proposal for the presentation of rack altalyses in ionic percentages: Aun. Aca, Sci. Fonnia, Ser, A, 3, 38 .

18. Ewell, R. H., and Imslcy, Herbert, 1935, Hydrothermal syathesis of kaolinite, diclite, beidellite, and nontronitc: U. S. Bur. Standards Jour. Research, v. 15, no. 2, p. 173-186.

19. Fenner, C. N., 1936, Bore-hole investigations in Yellowstone Park: Jour Geolog:, v, 42. no. 2. p. $225-311$.

20. Ferguson, H, G., and Bateman, A. M., 1912, Geologic features of tin deposits: Ecow. GEOL., v. 7, по. 3, p. 209-262.

21. Frederickson, A. F., and Cox, J. E., 1954, "Solubility" of albite in bydrothermal solutions: Am. Mineralogist, v. 39 , p. $738-749$.

22. Frondel, C., Hurlbut, C. S., Jr., and Collette, R. C., 1947, Synthesis of tournaline: $\Lambda \mathrm{m}$ Winerologist, $v .32$, nos, $12-12$, p. 68-681.

23. Grim, Ralph A., 1952, I953, Clay Mineralogy: McGraw-Hill Book Co., Inc., New York, N. Y., D. 38t.

2t. Gruner, J. W., 1944, The hydrothermal alteration of feldspars in acid solutions betwees $300^{\circ}$ and $400^{\circ}$ C: Econ. Grol., v. 39, p. 578-589.

25. Hanser, E. A., and Reynolds, H. H., 193\%, Alteration of glasses to montmorillonite: Am. Mineralogist, v. 24, p. 591-597.

26. Hemley, J. J., 1959, Sone mineralogical equilibria in the system $\mathrm{K}_{8} \mathrm{O}-\mathrm{Al}_{2} \mathrm{O}_{3}-\mathrm{SiO}_{4}-\mathrm{H}_{2} \mathrm{O}$ : Am. Jollr. Sci, v. 257, April, p. 241-270. 
27. Hosleing, K. T. G. 1951, Primnry ore depnsitinu in Cornwall : Royzl Geol. Soc. Cornivall Trans., v. 18, pr. 3, p. 309-356.

28. Hosli, Jost., 1951, Kaolin en Sudwestengland, Cornivall, der grosste Porzellanerde Product der Welt : Naturf. Ges. Zurich, Vicrteljahrssch, Jg. 96, H. 1, D. 43-70.

29. Joves, W. A., 1916, The origin of topaz and cassiterite at Gunong Bakau, Malaya: Geol. Mag. Decade VI, v. III, p. 255-260.

30. Kerr, P. F., 1950, Hydrothermal alteration at Santa Rita, New Mexico: Geol. Soc. Anerica Bull, v. 61, 0. $274-347$.

31. Knopi, Adolph, 1908, Geology of the Seward Peninsula tin deposits: U. S. Geol. Survey Bull. 358.

32. Knopf, Adolph, 1929, The Mother Lode system of Califordia: U. S. Geol. Survey Prof. Paper 157, p. 1-88.

33. Kullerud, $G_{.}$, 1953, The FeS-ZnS sy'stem, a geologic thermometer: Norsk geol. tidsskr., v. 32, p. $61-147$.

34. Lemberg, J., 1888, Zur Kenntniss der Bildung und Umwaldlang von Silicaten, Zeis: Deutsche geol. Gesell. Zeitschr, 40., p. 625-656.

35. Ligdgren, W., 1915, The osigin of kaolin: Ecor. GroL, v, 10, p. 89-92.

36. Lindgren, W., 1901, Metasomatic processes in fissure veins: Am. Inst. Min. Met. Eng. Trans., v. 30, p. 578-692.

37. Lovering, T. S., and others, 1949, Rock alteration as a guide to ore-East Tintic District, Utah: Econ. Geol. Mono.1, p. 1-6t.

38. Michel-Lévy, A., and Wyart, J., 1946, Reproduction synthétique de la topaze, de la cryolite, et du corindon: Soc. franç. mineralogic Bull. 69, 1956-161.

39. Morey, G. W., and Chen, W. T., 195S, The action of hot water on some feldspars: Am. Mineralogist, v. 40, p. $996-1000$.

40. Morey, G. W., and Ingerson, E., 1937, The pneumatolytic and hydrothermal alteration and synthesis of sillcates: Geopbysical Lab, Carnegie lnst. of Wash., paper no. 397.

41. Noll, W., 1936, Nenes Jahrbuch fur Mineralogie, Geologic und Palaontologie, Beilage Band. 70, p. 65-116.

42. Norton, F, H, 1941, Hydrothermal formation of clay minerals in the laboratory, part 2: Am. Mineralogist, v. 26, no. 1 , p. I-17.

43. Perrin, P., 1950. L'oxygene en les calculs pétrngraphiques, une discussion : Jour. Geology, v. $58, \mathrm{p}, 163-168$.

44. Poldervaart, Arie, 1953, Petralogical calculations in metasonatic processes: Am. Jour. Sci. v. 251, p. $481-507$.

45. Povarennyleh, A. S., i950. On certain products of hyogene alteration of topaz and muscovite: Akedemiya Nauk, SSSR, Doklady 75, p. 107-110.

46. Romo, L. A., and Roy, Rustum, 1955 , Essals de synthéses des minéraux dits a "conches mixtes": Soc, franc. Mineralogie, Bot. 78 , no. 7-9, p. 433-448.

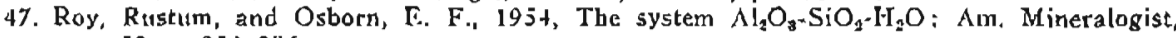
V. 39. P. $853-886$.

48. Roy, D. M., and Roy, Rustmm, 1955, Synthesis and stability in the systern $\mathrm{MgO}-\mathrm{N}_{9} \mathrm{O}_{2}$ $\mathrm{SiO}_{-2} \mathrm{H}_{8} \mathrm{O}$ : Am. Jour. Sci, v. 40, p. 147-177.

49. Sales, R. H., and Meyer, C. F., 1950, Interpretation of wall rock altcration at Buttc. Montana: Colorado School of Mines Quart. v. $\$ 5,0.261-274$.

50. Sand, L. B., Roy, Rustum, and Oshorn, E. F., 1954. The stability telations of some ninerals in the system $\mathrm{Na}_{3} \mathrm{O}-\mathrm{Al}_{\mathbf{8}} \mathrm{O}_{2}-\mathrm{SiO}_{2}-\mathrm{H}_{3} \mathrm{O}: \mathrm{Am}$, Mineralogist, v. 39 (abstract), p. 341 .

51. Schwarta, George M., 1947, Hydrothermal alteration in the porphyry copper deposits: Econ. GEol., v. 42, p. 319-352.

52. Shapiro, Leonard, and Brannock, W. W., 1956, Rapid analysig of silicate rocks: U. S. Geol. Suryey Bull. 1036-C.

53. Singewald, J. T., 1930, The Erzgebirge tin deposits: Ecov, GEoL., v. 25, no. 2, p. 211-218.

54. Smith, F. G., 1949, Laboratory testing of "pnemmatolytic" deposits: Ecox. Grol. v. 44, No. 7, p. $62+625$.

55. - 1947, Transport and deposition of the non-sulphide vein materials. II. Cassiterite: EcoN. GroL., v. 42, p. 319-352.

56. - 1949. Transport and deposition of the non-sulphide vein minerals. IV. Tourmaline: Econ. GeoL., v. 44, no. 3, p. 186-192.

57. Steidtmann, Edward, and Catheart, S. H., 1922, Geology of the Yark tin deposits, Alaska : U. S. Geol. Survey Ball. 733.

58. Steiner, A, 1953, Hydrothermal rock alteration at Wairakei, New Zealand: Econ. Grot., จ. 48, p. $1-13$. 
59. Stow, M. $\mathrm{H}, 1$ 1932, Authigenic tournaline in the Oriskany Sandstone: Am. Mineralogist, v. 17, p. $150-152$

60. Tooker, E. W., 1956, Altered wall rocks along vein deposits in the Centrgl City-Idaho Spriugs region, Colorado: Proc. 4th Nat. Cont. on Clays and Clay Min., Nat Acad. Sci. publication no, 456, p. 348-361.

61. Ussher, W. A. E., Barrow, G., and McAlister, D. A., 1909. The geology of the country around Bodwin and St. Austell: Great Britain Geol. Survey Mem., (explanation of map 347), p. $105-118$.

62. Vogt, J, H. L., 1895, Beitrage zur genetische classifaction der durch magmatische. Differentiationprocesse und der durch Pneumatolyses entstanden Erzvorkommen: Zeltschr. prakt. Geologie, p. 145-156, 46j-484.

63. White, D. E., 1955, Thermal springs and epithermal ore deposits: Ecos. Grol, 5th Annjv. Vol., pt. 1, p. 99-154. 